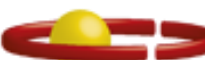 \\ UnC=UE \\ Centro Unıversıtárıo de Brasílıa \\ CENTRO UNIVERSITÁRIO DE BRASÍLIA - UniCEUB \\ PROGRAMA DE INICIAÇÃO CIENTÍFICA
}

\author{
Laís Brito Moraes da Silva \\ Daniel Moisés Martins
}

Interfaces entre a Psicologia e os direitos humanos: A atuação do profissional da psicologia no enfrentamento a violações de direitos humanos no Distrito Federal 


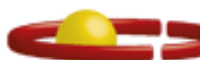 \\ UnTCEUs \\ Centro Unıversıtárıo de Brasílıa \\ CENTRO UNIVERSITÁRIO DE BRASÍLIA - UniCEUB \\ PROGRAMA DE INICIAÇÃO CIENTÍFICA
}

\author{
Laís Brito Moraes da Silva \\ Daniel Moisés Martins
}

Interfaces entre a Psicologia e os direitos humanos: A atuação do profissional da psicologia no enfrentamento a violações de direitos humanos no Distrito Federal

\author{
Relatório final de pesquisa de Iniciação Científica \\ apresentado à Assessoria de Pós-Graduação e \\ Pesquisa \\ Orientação: Lucas Alves Amaral
}

\section{BRASÍLIA}




\section{Agradecimentos}

Esta pesquisa se tratou de uma construção coletiva composta por muitas pessoas queridas. Nesse sentido, aqui expressamos algumas das pessoas a quem temos grande apreço e gratidão:

Primeiramente ao nosso querido orientador Lucas, pela confiança depositada em nós, pela sua humanidade ao longo desse processo e parceria desde o início da nossa

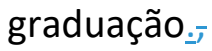

Aos nossos pais, pelo incentivo e encorajamento a nos tornar alguém melhor.

À nossa colega Ingrid, pois sem ela a submissão desse projeto não seria possível.

Ao professor Leonardo, por suas aulas inspiradoras e contribuição para a realização dessa pesquisa.

Ao Programa de Iniciação Científica do UniCEUB, por viabilizar a pesquisa.

Aos nossos colegas do curso de Psicologia do UniCEUB, que nos incentivaram a permanecer nesse processo.

Aos nossos amigos e parceiros, pelo suporte emocional, escuta atenta e implicada.

Ao grupo de estudos "Interfaces - Ciências Sociais, Psicologia e Direitos Humanos", por enriquecer nossos debates, inspirando-nos e nos dando abrilhantamento para o nosso desenvolvimento pessoal e, consequentemente, para o desenvolvimento deste trabalho.

Às nossas interlocutoras que nos compartilharam suas ricas experiências e sensibilidade, nos motivaram a seguir nesse percurso de enfrentamento às violações de direitos como profissionais de Psicologia. 


\title{
Interfaces entre Psicologia e os direitos humanos: a atuação do profissional da psicologia no enfrentamento a violações de direitos humanos no Distrito Federal
}

\author{
Laís Brito Moraes da Silva - UniCEUB, PIC institucional, estudante voluntária \\ lais.brito@sempreeub.com
}

Daniel Moisés Martins - UniCEUB, PIC Institucional, estudante bolsista

daniel.martins@sempreceub.com

Lucas Amaral - UniCEUB, professor orientador

lucas.amaral@ceub.edu.br

\section{Resumo}

A pesquisa desenvolvida busca desvelar e possibilitar uma compreensão crítica das percepções que as psicólogas da Penitenciária Feminina do Distrito Federal (PFDF) e do Consultório de Rua do Distrito Federal tem sobre direitos humanos e as violações desses direitos nos contextos nos quais atuam. Dessa forma, essa se configurou como um estudo de caso, munindo-se da realização e análise de entrevistas semiestruturadas e do desenvolvimento do método etnográfico. Ambos instrumentos de coleta de informação foram analisados a partir de um olhar cartográfico inspirado em Rolnik e Guattari (2000). Como resultado da pesquisa, definimos quatro tópicos analisadores baseados nas falas das entrevistadas: os dilemas da atuação profissional cotidiana; as escolhas e oportunidades na formação com vistas a realização de uma psicologia com compromisso social; as estratégias práticas de atuação envolvendo enfrentamento às violações de direitos humanos, e, por fim, as conexões presentes entre a rua e o presídio. O maior achado da pesquisa se deve a percepção de que no contexto de atuação da psicologia envolvendo a rua e o presídio a prática profissional é suscitada por escolhas individuais engajadas socialmente mais do que pelo incentivo externo de uma formação universitária. Além disso, durante a atuação tais profissionais se veem diante de possibilidades de intervirem de modo inovador e visando a emancipação dos públicos assistidos, bem como, paradoxalmente, diante de limitações e desengajamento em suas práticas, o que enxergamos como um certo tipo de endurecimento das subjetividades desses profissionais como psicólogos atuando nas fronteiras das interfaces com os direitos humanos.

Palavras-Chave: psicologia; direitos humanos; mulheres encarceradas; cárcere; pessoas em situação de rua; rua; psicologia, ciência e profissão. 
SUMÁRIO

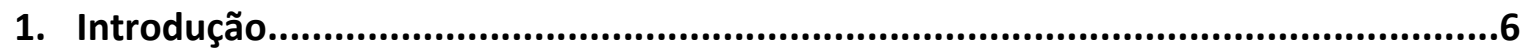

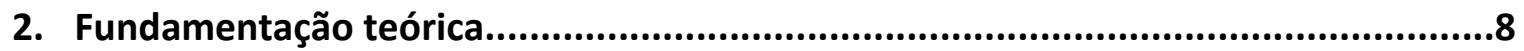

1.1. Psicologia, direitos humanos $\mathrm{e}$ as mulheres em situação de

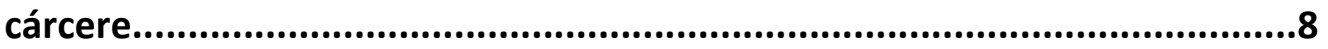

2.2. Psicologia, direitos humanos e pessoas em situação de

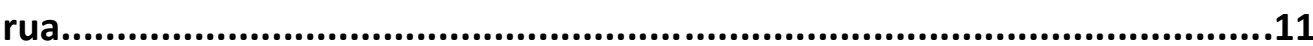

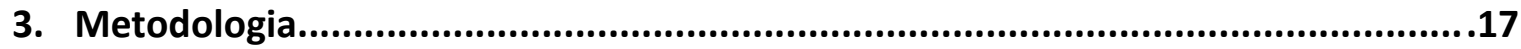

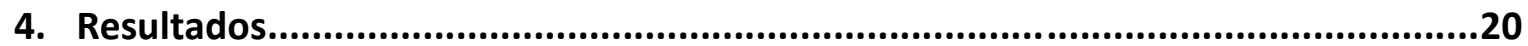

4.1. As escolhas e oportunidades na formação com vistas a realização de uma

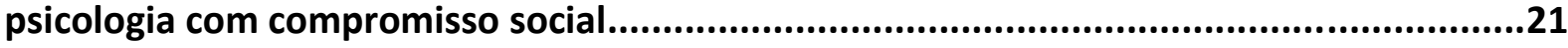

4.2 Os dilemas da atuação profissional cotidiana...................................................26

4.3. As estratégias práticas de atuação envolvendo enfrentamento à violações de

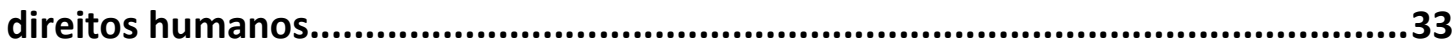

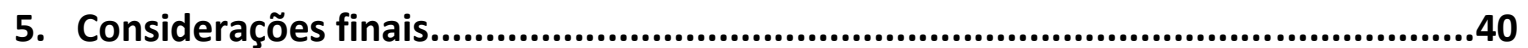

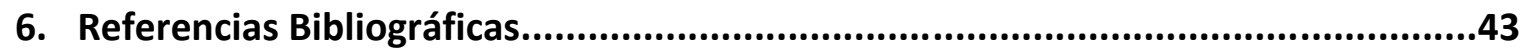




\section{Introdução}

Este relatório pretende refletir sobre a prática de profissionais da Psicologia em relação a pessoas em situação de rua (adiante PSR) e das mulheres em situação de cárcere (doravante MSC) no Distrito Federal (DF) e como tais práticas dialogam com a promoção dos direitos humanos desses grupos marginalizados em nossa sociedade. O estudo parte de um conjunto de reflexões produzidas no âmbito do Grupo de estudos e pesquisas "Interfaces: Ciências Sociais, Psicologia e Direitos humanos" sediado no curso de Psicologia do Centro Universitário de Brasília (UniCEUB). Como preocupação do grupo citado e da equipe de pesquisadores da pesquisa, o estudo aqui apresentado é considerado de extrema relevância política, científica e social, pois pretende perceber e analisar as concepções das psicólogas sobre sua atuação no cárcere, na rua e seu papel com o tema dos direitos humanos na prática. Bock (1999) aponta a necessidade de que o trabalho do profissional da psicologia deva contribuir para a transformação social e para a mudança das condições de vida da população brasileira. Essa atuação de uma Psicologia implicada com as questões sociais, também, é pouca estudada (Bock, 1999; Balbino, 2007; Rosato, 2011). Nosso objetivo é obter uma visão mais ampla e complexa acerca das dificuldades e estratégias encontradas por essas profissionais em campo, bem como acerca das vulnerabilidades e exclusões vivenciadas pelas clivagens sociais assistidas por elas.

Balbino (2007) nos aponta que, historicamente no campo da Psicologia brasileira, muitas práticas profissionais psicológicas reproduziram desigualdades e preconceitos. Essa afirmação foi corroborada por nossas amplas buscas bibliográficas que nos relevaram não existirem muitas pesquisas que analisem a atuação do profissional da psicologia em relação às MSC e às PSR no Brasil. Por outro lado, autoras, tais como Balbino (2007) e Rosato (2011) observam uma tendência recente no campo da Psicologia no Brasil de se buscar ressaltar a importância do enfrentamento a violações de direitos humanos no campo da Psicologia. Esse processo tem se dado pela produções de Resoluções do Conselho Federal de Psicologia, encontros, seminários, entre outros. Balbino (2007) afirma, inclusive, que pesquisas como esta, que buscam explorar a relação entre Psicologia e direitos humanos, são essenciais para que se crie subsídios teórico-práticos com fins a incluir no currículo da graduação em Psicologia disciplinas voltadas ao engajamento social e teórico com a temática dos direitos humanos e criar projetos de ensino, pesquisa e extensão sobre o tema. 
Dito isso, antes de irmos adiante, é relevante apontarmos que não entendemos direitos humanos a partir de um viés filantrópico das declarações e revoluções burguesas ocorridas no passado, considerando que a gênese desses direitos ocorreu em um contexto societário elitista no qual não deu possibilidades de inclusão de classes mais desfavorecidas (COIMBRA et al, 2008). Como afirmou Deleuze (1992), a gênese dos direitos humanos teria gerado uma ilusão de que os subalternizados têm a atenção das elites; o que não é a expressão da realidade brasileira. Ao contrário, vimos que, historicamente, muitas vezes tais direitos foram instrumentalizados por elites para reproduzir práticas violentas contra os mesmos grupos que formalmente os direitos humanos visavam proteger. Partimos, portanto, de uma compreensão crítica acerca dos direitos humanos e sua articulação com a Psicologia. Entendemos que o compromisso ético e político da Psicologia, das práticas e reflexões mais simples às mais complexas, das intervenções mais individuais às mais coletivas, é a de produzir um posicionamento ativo frente às violações de direitos humanos de populações vulneráveis, assumindo, como dito, o seu compromisso social enquanto ciência e profissão (BOCK, 1999).

Consideramos a Psicologia um campo profissional de extrema importância no enfrentamento às violações de direitos humanos. Segundo Rosato (2011) os cursos e percursos da Psicologia e dos Direitos Humanos se cruzam na finalidade da garantia de dignidade humana às minorias e excluídos sociais. Bento (2001), por sua vez, demonstra-nos que, embora a Psicologia praticada no século XIX na Europa e importada pelo Brasil no século XX ter sido muitas vezes preconceituosa e excludente em suas ações e, consequentemente, promotora de violações, nos tempos atuais a intervenção do profissional da Psicologia no mundo social pode contribuir para construir os direitos humanos e enfrentar violações em uma determinada sociedade.

A tendência produtiva na interação entre Psicologia e direitos humanos, da qual este trabalho faz parte, busca dialogar, também, com o Código de Ética Profissional da Psicologia. O Código, de fato, afirma, como primeiro princípio fundamental, que o profissional da psicologia deve basear seu trabalho no respeito e promoção da liberdade, dignidade, igualdade e integridade do ser humano, apoiando-se nos valores que embasam a Declaração dos Direitos Humanos (CFP, 2005). A partir de todos os elementos levantados acima, entendemos que a maior contribuição da pesquisa aqui discutida é justamente a de fomentar a produção acadêmica sobre as interfaces entre Psicologia e direitos humanos, 
fazendo isso a partir de uma elaboração interdisciplinar que dialoga com as Ciências Sociais. Nosso ponto de partida, portanto, é mediado por uma posição político-epistemológica de defesa de uma prática da Psicologia engajada com compromissos sociais. Sendo assim, e, a partir do que foi dito, o objetivo geral da pesquisa é analisar as trajetórias de formação profissional da Psicologia, bem como as suas práticas profissionais em contextos de violações de direitos humanos no Distrito Federal.

Por fim, este relatório de pesquisa se organiza da seguinte forma. Nesta Introdução apresentamos o tema da pesquisa, sua contextualização, as justificativas e contribuições políticas, sociais e científicas da pesquisa, bem como os objetivos da pesquisa realizada. $\mathrm{Na}$ primeira seção, discutimos alguns temas de fundamentação teórica da pesquisa advindos da revisão da literatura feita pela equipe pesquisadora antes e durante o processo de pesquisa, tais como: a relação entre psicologia e direitos humanos, o campo de atuação de profissionais da psicologia em relação às mulheres em situação de cárcere e pessoas em situação de rua, bem como a própria condição desses grupos na sociedade brasileira. $\mathrm{Na}$ segunda seção do texto, apresentamos a metodologia qualitativa utilizada na pesquisa. $\mathrm{Na}$ terceira seção, por sua vez, discutimos o que consideramos os resultados da pesquisa. Os resultados da pesquisa são divididos em três subseções: 1 . as escolhas e oportunidades na formação com vistas a realização de uma psicologia com compromisso social; 2 . os dilemas da atuação profissional cotidiana; 3. as estratégias práticas de atuação envolvendo enfrentamento à violações de direitos humanos. Por fim, apresentamos as Considerações finais deste relatório de pesquisa, espaço no qual discorremos sobre algumas conexões entre a rua e o presídio problematizadas por nossas interlocutoras, e discutimos o que consideramos os maiores "achados" da pesquisa, indicando, também, lacunas e caminhos para pesquisas futuras.

\section{Fundamentação teórica}

\subsection{Psicologia, direitos humanos e as mulheres em situação de cárcere}

À título de contextualização, no que tange às mulheres em situação de cárcere, o Brasil é o quinto país no mundo com a maior população carcerária feminina e a superlotação constitui um problema sério no que tange à reabilitação e contenção sadia e segura dessas 
mulheres (DEPEN, 2014). Segundo dados do DEPEN (2014), os principais motivos para as pessoas em conflito com a lei, em geral, chegarem a ser encarceradas são por crimes contra patrimônios (46\%), capturados pela lei de drogas (28\%), pelo estatuto do desarmamento (13\%), por crimes contra a dignidade sexual (5\%), contra a paz pública (4\%), além de crimes contra administração pública e por crimes de trânsito (4\%). Além disso, outros dados relevantes são que $64 \%$ das mulheres encarceradas no Brasil estão nessa situação em decorrência de tráfico de drogas e 19\% delas por roubos e ou furtos. Com relação a esse dado, há um debate notório acerca da inserção dessas mulheres no mundo do tráfico mediadas por relações desiguais com homens, não só no Brasil, mas também na América Latina, já que a maioria das mulheres encarceradas por tráfico de drogas alegam terem sido aliciadas pelos parceiros ou parentes (GIACOMELLO, 2013). Além disso, fatores como a alta quantidade de prisões preventivas e os incentivos de políticas públicas de prevenção de drogas são relevantes para compreender o que leva as instituições carcerárias a enfrentarem o excedente de internos (FIGUEIRÓ, 2015). Ainda há que se complementar o quadro descrito aqui com o fato de que a trajetória de vida da maioria das mulheres encarceradas no Brasil é marcada, em geral, pela pobreza, a inserção no tráfico de drogas, o baixo grau de escolaridade e o uso de drogas, condições de um cenário de vida vulnerável que perpassa ausência ou violações de direitos básicos em várias etapas de suas vidas, inclusive, no cárcere (CORTINA, 2015; FERRARI, 2010 e SCHERER \& SCHERER, 2009).

Historicamente, segundo Coimbra (2008), embora, em tese, hoje, as instituições carcerárias sejam regidas por regras que consideram os direitos humanos e a necessidade de universalização desses direitos, essas surgem no Brasil mediadas pela necessidade de se dar visibilidade científica ao chamado "indivíduo perigoso". Buscava-se gerar uma nova prática de punição para as pessoas que transgredissem as leis, através de um viés positivista de ordenação social através de uma "normalização" das populações. Em 1945 ganhou visibilidade o campo da Psicologia jurídica como um meio de institucionalizar práticas desviantes através de perfis psicológicos potencialmente transgressores. Um dos grandes objetivos da psicologia jurídica era intervir na sociedade para resolver problemas de desajustamento em situações tidas como problemáticas (COIMBRA, 2003). Dessa forma, ocorre a inserção dos profissionais da psicologia no sistema penitenciário brasileiro. Esse processo se torna formal, após a regulamentação da profissão "Psicologia" no ano de 1962, 
que passa a ser praticada principalmente no Rio de Janeiro ${ }^{1}$. A entrada dos psicólogos em instituições de justiça ocorreu, principalmente, nos - chamados assim à época "manicômios judiciais", dentro dos quais eram, literalmente, "despejados" as pessoas que transgredissem regras diversas e que apresentassem algum distúrbio em sua saúde mental, à época chamados de "loucos infratores" (CFP, MINISTÉRIO DA JUSTIÇA, 2007). Esses não poderiam ser penalizados no sistema carcerário tradicional por não pertencerem à lógica de "normalidade". A inserção dos psicólogos nos presídios, em geral, no país ocorreria posteriormente.

Após a breve contextualização geral sobre a inserção do profissional da Psicologia nas instituições carcerárias no Brasil é importante ressaltar que esses profissionais tinham como principais funções no sistema carcerário a elaboração de laudos e pareceres realizados a fim de avaliar a periculosidade criminal do sujeito encarcerado. Tais laudos e pareceres eram usados em concessões de benefícios ou numa possível finalização da pena (RAUTER, 2007). No entanto, os profissionais da Psicologia lutaram para o fim da obrigação dessa função ao longo dos anos 2000, dado que a emissão de laudos e pareceres implica, do ponto de vista do sujeito apenado, em uma prática potencialmente punitiva. A dimensão dialógica e terapêutica da relação entre profissionais da Psicologia e pessoas em conflito com a lei comprometia profundamente a relação clínica e a construção de vínculos de confiança ${ }^{2}$. Em meados dos anos 2000 foi aprovada uma resolução do Conselho Federal de Psicologia sobre a não obrigatoriedade dos profissionais de Psicologia de realizarem prescrição de exames criminológicos ou de participarem em comissões disciplinares no âmbito das instituições carcerárias no Brasil. Atualmente, no entanto, segue um projeto de lei no Congresso Nacional para que o laudo volte a entrar em vigor.

\footnotetext{
${ }^{1}$ CFP; Ministério da Justiça. Diretrizes para Atuação e Formação dos Psicólogos do sistema prisional brasileiro. Brasília, 2007. Disponível em: https://site.cfp.org.br/wp-content/uploads/2012/07/depen cartilha.pdf

${ }^{2}$ Art. $2^{\circ}$. Em relação à atuação com a população em privação de liberdade ou em medida de segurança, a(o) psicóloga(o) deverá: ... Parágrafo Único: É vedado à(ao) psicóloga(o) participar de procedimentos que envolvam as práticas de caráter punitivo e disciplinar, notadamente os de apuração de faltas disciplinares. Art. $4^{\circ}$. Em relação à elaboração de documentos escritos para subsidiar a decisão judicial na execução das penas e das medidas de segurança: a) A produção de documentos escritos com a finalidade exposta no caput deste artigo não poderá ser realizada pela(o) psicóloga(o) que atua como profissional de referência para o acompanhamento da pessoa em cumprimento da pena ou medida de segurança, em quaisquer modalidades como atenção psicossocial, atenção à saúde integral, projetos de reintegração social, entre outros. ... $\S 1^{\circ}$. Na perícia psicológica realizada no contexto da execução penal ficam vedadas a elaboração de prognóstico criminológico de reincidência, a aferição de periculosidade e o estabelecimento de nexo causal a partir do binômio delito delinquente.) (CFP, Resolução n. 12/2011).
} 
Segundo nossas entrevistadas, o grande papel do profissional da Psicologia no sistema prisional atualmente é instruir as pessoas em conflito com a lei acerca de seus direitos e deveres, bem como contribuir para o aumento de sua qualidade de vida em condições adversas, já que o sistema prisional brasileiro se apresenta superlotado e sua população é excluída de diversos espaços e debates sociais relevantes, merecendo uma atenção especial no que tange às suas condições de vida (CARVALHO, VALENTE, ASSIS \& VASCONCELOS, 2006).

É importante para os nossos debates entender os presídios como "instituições totais" ou seja, como instituições nas quais os modos de vida (dormir, acordar, comer, conviver, trabalhar, descansar, etc) de um contingente de sujeitos (as internas, no caso de uma Penitenciária) perpassam a totalidade de suas vida cotidiana. A população interna das instituições carcerárias compartilham de situações semelhantes de aprisionamento por tempo determinado e são administradas por grupos de gestores e profissionais que desfrutam de privilégios no âmbito da instituição, logo, em geral, vivem de modos muitos distintos da população interna para além dos muros da instituição. Essa distinção entre aqueles que são assistidos e aqueles que são os gestores no interior de uma Penitenciária cria uma contexto relacional em que os diferentes grupos encontrem dificuldades de estabelecerem vínculos emocionais. Pelo contrário, a tendência se torna o estabelecimento de uma forma de tratamento que objetifica e homogenieza os internos, sem percebê-los como pessoas singulares, com trajetórias singulares (GOFFMAN, 1999). Segundo Goffman (1999), nas instituições totais ocorre o que chama de "mortificação do eu" dos grupos internos às instituições carcerárias, pois esses vivem uma separação completa do mundo externo, são tratados muitas vezes a partir da tipificação dos crimes que cometeram, usam roupas e tem cuidados higiênicos iguais, recebem visitas esporádicas de pessoas externas, tem notícia reduzida sobre os acontecimentos sociais em geral da sociedade englobante, além de passarem, muitas vezes, por humilhações, degradações e profanações de si experiências que tendem a desconstruir a sua visão de si mesmo e sua identidade. A partir do que foi dito, entendemos que o papel de cuidado e escuta executado por profissionais da Psicologia pode ser fundamental para as pessoas em conflito com a lei no interior de instituições carcerárias. 
Por fim, o estudo de caso analisado sobre a atuação de profissionais da Psicologia em relação a mulheres em situação de cárcere, é marcada pelo debate de gênero ${ }^{3}$ e o papel das mulheres, seja como profissionais da Psicologia, sejam como detentas. As relações de poder se estabelecem de diversas formas, no entanto, quando o tema das relações de gênero vem à tona, entende-se que há elementos culturais nos quais se naturalizam a relação da dominação masculina, tal como é possível notar, por exemplo, na linguagem e nas práticas culturais, o valor simbólico dos corpos compreendido nessa estrutura de dominação (BOURDIEU, 2014). Ocupar a posição do gênero feminino, portanto, é estar em constante local de subalternidade e sujeita a humilhações em nossa sociedade (BIROLI \& MIGUEL, 2014).

As questões de gênero relacionadas aos papéis tradicionais das mulheres na sociedade são bastante presentes no ambiente carcerário, no qual prevalecem concepções patriarcais e masculinas em seu escopo simbólico (DINIZ, 2015; BARCNSKI, 2014). Barcinski (2014) aponta que diferente dos homens, as mulheres em situação de cárcere sofrem estigmatizações para além dos crimes pelo qual foram apenadas, por não terem conseguido cumprir com um de seus principais papéis de gênero: a maternidade. A autora aponta também que o controle sobre os corpos dessas mulheres, em geral, são mais "dóceis" (não em termos focaultianos), no sentido das regras das instituições carcerárias controlarem as suas vestimentas, a vaidade feminina e também o uso de maquiagens, elementos importantes da constituição da subjetividade feminina na sociedade capitalista contemporânea.

Diante disso, Diniz (2015) aponta a importância de, além de se pesquisar o cárcere, orientar a os relatos de pesquisa de uma forma que diferencie da lógica patriarcal, porque, segundo a autora, há uma marca latente de práticas violentas e punitivas no contexto prisional. Sendo o cárcere historicamente um dos ambientes mais vulneráveis às violações dos direitos humanos e os "efeitos invisibilizantes" (BARCINSKI, 2014) que as mulheres passam nesse ambiente, optamos investigar em que medida as psicólogas que atuam no Presídio Feminino do Distrito Federal (PFDF) estão comprometidas com o enfrentamento às violações dos direitos humanos, bem como saber as dificuldades e limitações da sua

\footnotetext{
${ }^{3}$ Entendemos por gênero uma construção social que dá margem a uma série de desigualdades entre as pessoas.
} 
atuação, compreender os diálogos que fizeram entre cárcere e Psicologia e direitos humanos, desde sua formação universitária até o seu dia-a-dia como profissionais da PFDF.

É importante colocar que é latente na trajetória de vida das mulheres encarceradas a pobreza, a inserção no tráfico de drogas, o baixo grau de escolaridade e o uso de drogas. Tais condições podem indicar um cenário vulnerável que contribui para levar essas mulheres à prisão (CORTINA, 2015; FERRARI, 2010 e SCHERER \& SCHERER, 2009). Além disso, considerado um problema de saúde pública universal (CARVALHO, VALENTE, ASSIS \& VASCONCELOS, 2006), as prisões, cuja população é excluída de diversos espaços e debates, merecem uma atenção especial no que tange às condições de vida e infraestrutura por serem um espaço de confinamento propenso à "mortificação do eu", (GOFFMAN, 1961/1999).

\subsection{Psicologia, direitos humanos e pessoas em situação de rua}

As pessoas em situação de rua no Brasil são constantemente alvo de noções preestabelecidas que perpassam o imaginário social. Segundo Mattos e Ferreira (2004), a partir de levantamento sobre tais noções a partir de pesquisa qualitativa no Brasil, as pessoas em situação de rua são estigmatizadas como "sujas", "drogadas", "vagabundas", "perigosas", "loucas" e "coitadas". Não se limitando apenas a esse tratamento objetificante de suas identidades, no Brasil muitas PSR são alvos corriqueiros de violências hostilidades diversas e, em alguns casos, até mesmo de mortes. Casos como o massacre da Candelária no Rio de Janeiro ou o homicídio do índio Galdino, que foi queimado nas ruas de Brasília, infelizmente, não são raros no Brasil; o que coloca as pessoas em situação de rua em um nível de exclusão não só econômica e social, mas exclusão do próprio rol de humanidade (BAUMAN, 2005). Essas práticas de exclusão e estigmatização afetam o processo de produção das identidades das PSR. Essas passam a ser marcadas por um forte processo de cristalização de sua identidade social, tornando-se "tipificadas" pela vista da sociedade que se considera "normal" por viverem residências. As PSR passam a ser vistas a partir da sua exclusão do projeto de produção capitalista contemporâneo (BAUMAN, 2005). O ápice de sua "tipificação" é a completa apreensão da pessoa como um "tipo", somente pelos aspectos rotulados, negando sua humanidade e a transformação a ela inerente (MATTOS E FERREIRA, 2004). 
Acerca da representação sobre pessoas em situação de rua e o universo trabalho, prática considerada muito importante na sociedade global atual, temos que a sociedade brasileira atual se estrutura a partir de uma lógica simbólica de supervalorização da prática do trabalho, ideia sintetizada na frase "o trabalho dignifica o homem". O trabalho é considerado um fator primordial para a pessoa humana no sistema de valores hegemônicos da sociedade capitalista por dois aspectos: em primeiro lugar, provém a subsistência física por meio dos rendimentos auferidos; e, em segundo lugar, pois o trabalho sustenta a subsistência simbólica das pessoas como profissionais ou "empregadas" em um trabalho, dada a importância do trabalho para a identidade profissional, logo, para a identidade pessoal da grande maioria das pessoas de nossa sociedade (MATTOS \& FERREIRA, 2004). Muitas das pessoas em situação de rua no Brasil apresentam atividades de trabalho consideradas menores por serem informais, como, por exemplo, a atividade de "catador de latinhas" ou a de "flanelinha". Na percepção geral da população, a partir das representações hegemônicas, as atividades citadas são consideradas "inúteis" e "improdutivas", realizadas por pessoas "vagabundas", na tentativa de ganhar uma pequena quantia de dinheiro para o seu sustento imediato, sem planejamentos futuros. Nas palavras de Escorel (1999: p.219), buscando discutir os modos de vida de PSR, "na rua, o que se ganha se gasta de imediato. Por vezes, a tarefa é realizada apenas durante o tempo necessário para conseguir comprar uma refeição ou pagar a hospedagem em pensões baratas".

Dentro do imaginário social mais amplo, pode-se perceber um pensamento reducionista de que as PSR não possuem um trabalho porque "não querem trabalhar", estudar ou se profissionalizar, esquecendo-se da realidade vivenciada por essas pessoas cotidianamente e do seu processo biográfico. Além disso, esquece-se de que, no Brasil, uma sociedade historicamente marcada por desigualdades sociais e econômicas desde o processo de colonização, a população, em geral, não tem acesso a iguais oportunidades no que tange às oportunidades econômicas. Soma-se a isso elementos sociológicos mais complexos. Bauman (2005), por exemplo, argumenta que a sociedade moderna fabrica modelos ou projetos de vida fundamentados no desejo capitalista de "formar-se", "empregar-se", "possuir bens" e "ser bem sucedido". O emprego é visto como "a chave para solução dos problemas ao mesmo tempo da identidade pessoal socialmente aceitável, da posição social segura, da sobrevivência individual e coletiva, da ordem social e da reprodução sistêmica" (BAUMAN, $2005 ; 19)$. 
Além do que foi dito, os estereótipos das pessoas em situação de rua vêm de encontro com aquilo que é considerado socialmente "anormal", associando-as à "loucura". Segundo Mattos e Ferreira (2004) se morar em uma residência fixa, trabalhar formalmente e constituir família são padrões sociais que caracterizam os indivíduos "normais", logo, sem residência fixa, sem família e trabalho formal, as pessoas em situação de rua são alvos constantes de investidas ideológicas que acentuam suas "anormalidades". Além de "loucas", muitas representações sobre a higiene e limpeza das pessoas em situação de rua são evocadas. Normalmente tais pessoas são caracterizadas pelo seu "mau cheiro", a queda de alguns dentes, roupas rasgadas, o "pé preto" e "descalço", unhas tortas e escurecidas, feridas, cicatrizes e etc.

Além do já dito, consideramos importante tentar entender como as PSR sobrevivem na rua. Muitas delas encontram seus subsídios de sobrevivência no descarte e na coleta do lixo. Não é raro ver uma pessoa revirando contêineres de lixo a procura de alimentos, roupas ou objetos que possam ser "reaproveitados", produção de subsistência que as aproxima da ideia de "refugos humanos" (BAUMAN, 2005). Acerca dos refugos humanos, Bauman (2005) diz que a condição de excluída aproxima a PSR à uma "coisa". Essa "coisa", sem domicílio e sem função, transpõe a barricada que separa a ordem do caos. Sua extirpação é o último ato de criação antes que se concluam os trabalhos de construção da ordem" (BAUMAN, 2005; p. 43).

Segundo Mattos e Ferreira (2004) existe também um discurso religioso acerca das PSR, que as colocada como "dignas de piedade", sendo consideradas "coitadas". Esse ponto de ser digno de piedade fortalece a visão de inferioridade e incapacidade dessas pessoas. Muitas vezes essa visão inviabiliza a tentativa dessa pessoa de sair dessa condição/situação ou as vezes ela pode internalizar e acreditar que ela não é capaz de nada. Por fim, outro estereótipo das pessoas em situação de rua é que são pessoas "perigosas", noção bastante influenciada por um discurso jurídico e criminológico. Por se tratar de uma pessoa esteticamente suja, socialmente "anormal" e pobre, as pessoas tendem a manter uma distância por causa do medo e porque enxergam a pessoa em situação de rua como um criminoso em potencial.

Dito isso, na sociedade contemporânea mediada por direitos sociais e ancorada nos princípios da dignidade humano, atualmente cabe ao Estado a provisão de alguns serviços às PSR, tais como adotar e implementar estratégias para eliminar a falta de moradia 
adequada, distribuir responsabilidades a todos os níveis governamentais em união com as pessoas em situação de rua, combater e prover proteção legal contra à discriminação as quais essas pessoas estão sujeitas. Serviços relacionados à saúde mental e provisão de apoio psicológico são um desses deveres estatais previstos na noção de garantia da dignidade humana das PSR. Dessa forma, profissionais da Psicologia atuam hoje em diferentes aparatos institucionais em atenção à PSR, tais como: Serviços de Acolhimento Institucional, Serviços de Acolhimentos em República, Centro POP, Consultório de Rua e CAPSad (Centro de Atenção Psicossocial de Álcool e Drogas).

Os Consultórios de Rua, instituições em que atuam duas psicólogas entrevistadas nesta pesquisa, é caracterizado pela atuação do profissional da Psicologia no próprio espaço da rua. Trata-se de

\footnotetext{
"uma modalidade de atendimento extramuros dirigida aos usuários de drogas que vivem em condições de maior vulnerabilidade social e distanciados da rede de serviços de saúde e intersetorial. São dispositivos clínico-comunitários que ofertam cuidados em saúde aos usuários em seu próprio contexto de vida, adaptados para as especificidades de uma população complexa. Promovem a acessibilidade a serviços da rede institucionalizada, a assistência integral e a promoção de laços sociais para os usuários em situação de exclusão social, possibilitando um espaço concreto do exercício de direitos e cidadania." (CRP-MG, 2015, p. 30).
}

No sistema institucional que visa assistir as PSR no Brasil, temos ainda os Serviços de Acolhimento Institucional e em República. "A especificidade desses serviços está na oferta de proteção integral que garanta condições de estadia, convívio, endereço de referência, para acolher com privacidade pessoas em situação de rua". (CRP-MG, 2015, p. 26).

Além disso, temos o Centros de Atenção Psicossocial Álcool e Drogas (CAPSad), nos quais ofertam os serviços de atenção a pessoas com vício em álcool e drogas. O CAPSad é uma extensão do serviço fornecido pelo Centros de Atenção Psicossocial (CAPS), no qual é voltado para pessoas com sofrimento mental. Seu objetivo é oferecer atendimento à população "realizando o acompanhamento clínico e a reinserção social dos usuários, pelo acesso ao trabalho, lazer, exercício dos direitos civis e fortalecimento dos laços familiares e comunitários" (BRASIL, 2009c, p.73).

O Centro de Referência Especializado para a população de rua, chamado de Centro POP, por sua vez,

"oferta atendimento a moradores de rua, adultos, de ambos os sexos, que chegam espontaneamente ou encaminhados pela rede de atendimento e possui como objetivos o fortalecimento do vínculo dos usuários com a equipe, possibilitando encaminhamentos diversos que visem à superação da situação de rua; 
a contribuição com a melhoria da autoestima; o despertar do desenvolvimento de consciência crítica com relação à cidadania, direitos e deveres; e o acompanhamento do usuário a partir das demandas apresentadas" (CRP-MG, 2015, p. 27).

Por fim, além dos órgãos, instituições e serviços citados acima, o Conselho Federal de Psicologia (CFP) vem promovendo uma ampliação da concepção acerca da contribuição da Psicologia nas políticas públicas sociais, baseando-se em uma noção de Psicologia que valoriza a atuação e o estabelecimento de práticas comprometidas com a transformação social e a emancipação humana. Nessa linha, foi criado o Centro de Referência Técnica em Psicologia e Políticas Públicas (CREPOP), que busca identificar práticas relevantes, sistematizá-las e disponibilizá-las para toda a sociedade. O CREPOP tem por objetivo produzir informação qualificada que amplie a capacitação dos psicólogos na compreensão das políticas públicas e teórico-técnica em relação aos serviços que hão de ser prestados. $\mathrm{A}$ partir dessa iniciativa do CFP, surgiu, também, a articulação entre a Psicologia e a Assistência Social dentro dos Centros de Referência de Assistência Social (CRAS). No CRAS a atuação do Psicólogo visa priorizar as potencialidades presentes nos sujeitos, famílias e comunidades, com foco na prevenção e promoção da vida e, de forma geral, o enfrentamento e a desnaturalização da violação dos direitos. Segundo Cesário (2017), a grande importância da construção e articulação de toda essa rede de assistência psicossocial é a de promover a autonomia das PSR. Na mesma linha, afirma uma cartilha do Centro de Referência Técnica em Psicologia e Políticas Públicas:

\footnotetext{
"a capacidade de enfrentamento das situações de vida é afetada pelas experiências, condições de vida e significados construídos ao longo do processo de desenvolvimento, e o trabalho para com um indivíduo envolvido em uma lógica de vulnerabilidade social, exclusão e opressão é o de construção de novos significados, de forma a promover e fortalecer vínculos sócio-afetivos, e contribuir para o reconhecimento de sua identidade, poder pessoal e de seu papel ativo como construtor e transformador de suas realidades" (CREPOP, 2007: 17-18)
}

\section{Metodologia}

Em termos metodológicos, a pesquisa aqui discutida se configurou em um estudo de caso, dado que este é um recurso metodológico que visa orientar o nosso olhar de forma holística afim de apreender diversas facetas de um mesmo fenômeno (ALMEIDA, 2016). 
Consideramos o estudo de caso como o instrumento metodológico mais adequado para geração de conceitos e hipóteses sobre processos complexos (RUESCHEMEYER, 2003)

Dito isso, a pesquisa, de um modo geral, visa analisar a "a atuação do profissional da psicologia no enfrentamento a violações de direitos humanos no Distrito Federal". Para realizar tal tarefa foi necessário ramificar o tema em dois estudos de caso específicos, com a finalidade de criar uma unidade independente e menos genérica para a pesquisa e análise, bem como criar possibilidades de, futuramente, produzir comparações entre ambos casos, além de explorar outros campos da temática mais ampla da pesquisa. Os casos aqui analisados, portanto, são: "a atuação de profissionais da psicologia em relação a mulheres em situação de cárcere"; e "a atuação de profissionais da psicologia em relação a pessoas em situação de rua".

Para realizar a análise, primeiramente, foi realizada ampla revisão da literatura teórica sobre as interfaces entre psicologia e direitos humanos, a partir de uma ótica das ciências sociais. Além desse tema, foi revisada a bibliografia e feita pesquisa de documentos sobre mulheres, gênero e cárcere, foram feitas pesquisas sobre a atuação de profissionais da psicologia no cárcere (masculino e feminino) no Brasil, principalmente, em penitenciárias femininas no Brasil e, em especial, no Distrito Federal. Do mesmo modo, a revisão da bibliografia do caso que analisa a atuação de profissionais da psicologia junto a PSR analisou as violências e estereótipos sofridas por essas pessoas, e as representações sociais hegemônicas acerca delas. Além disso, da mesma forma que no outro caso, nesse caso foram feitas pesquisas bibliográficas diversas, bem como foi feita pesquisa de documentos, sobre a atuação de profissionais da psicologia em relação a pessoas em situação de rua no Brasil, especialmente, no Distrito Federal.

Após os várias meses de leitura e debates e análise documental diversa, o projeto da pesquisa foi submetido e aprovado pelo Comitê de Ética do UniCEUB. Como compromisso firmado na submissão do projeto junto a esse Comitê, cada entrevistada recebeu um Termo de Consentimento Livre e Esclarecido (TCLE) assinado pela equipe pesquisadora, esclarecendo os riscos, bem como os comprometimentos éticos da pesquisa em relação ao sigilo de suas identidades, bem como o compromisso de publicitação das reflexões, e deixando as participantes livres para desistirem em qualquer momento de sua participação na pesquisa. Ainda em compromisso as participantes e como pacto firmado na assinatura do TCLE, optamos por preservar as identidades pessoais das entrevistadas. 
Simultaneamente às leituras, debates e análise de documentos, e à submissão do projeto à aprovação do Comitê, foi realizado intenso mapeamento das instituições onde os profissionais da psicologia atuam no Distrito Federal (órgãos governamentais, organizações da sociedade civil, movimentos sociais, entre outros) para cada caso analisado. No caso das mulheres em cárcere a única instituição estatal encontrada no Distrito Federal foi a Penitenciária Feminina do Distrito Federal (PFDF). No caso das pessoas em situação de rua encontramos várias instituições estatais, bem como projetos sociais, apresentados na seção a seguir. Dentre esses, identificamos no Consultório de Rua do DF aquela instituição que mais se aproximava do objetivo geral da pesquisa, possibilitando-nos perceber práticas profissionais da psicologia que rompem com lógicas temporais e espaciais tradicionais.

Após a identificação da PFDF e do Consultório de Rua como as institucionalidades através das quais gostaríamos de analisar as práticas dos profissionais da Psicologia e sua interação com a temática dos direitos humanos, iniciamos um processo de mapeamento de quais eram os profissionais "psi" atuantes nessas instituições, bem como realizamos diversos contatos com aqueles profissionais mapeados, através de mensagem eletrônica e via ligação telefônica. Em ambos os casos analisados, as primeiras profissionais com quem conseguimos diálogo e aceite para realização de entrevista foram indicadas pela rede de contatos de profissionais da Psicologia do Centro Universitário de Brasília (UniCEUB), tendo sido as profissionais entrevistas logo a seguir indicadas pelas primeiras Após várias tentativas com maior número de profissionais possível, além de termos recebido algumas negativas, foi possível realizar quatro entrevistas semiestruturadas com quatro psicólogas, duas atuantes na Penitenciária Feminina do Distrito Federal (PFDF) e duas atuantes no Consultório de Rua do Distrito Federal.

As quatro entrevistadas são mulheres, dado que as todas as profissionais da Psicologia da PFDF são mulheres e dado que existe uma proporção pequena de psicólogos homens atuantes atualmente no Consultório de Rua, bem como por possibilidade de acesso nos foi possível acessar apenas duas mulheres. Dessa forma, orientados por Diniz (2012), optamos neste relatório de pesquisa pelo recurso de uma escrita que escreve "psicólogas" (no feminino) ao invés de "psicólogos" (no masculino) para generalizar os profissionais da área, honrando a identidade daquelas pessoas que realmente foram entrevistadas, bem como considerando o "as" como referencial universal para se referir às pessoas em geral, 
como até aqui tendo sido feito nas diferentes tradições de pesquisas em Ciências Sociais e Psicologia ,os dois campos disciplinares com os quais dialogamos, com o gênero masculino.

Além do que já foi dito, e, de modo complementar, foi desenvolvida breve observação participante em alguns contextos interacionais de aplicação de entrevistas semiestruturadas e em eventos sobre a atuação de profissionais, principalmente, no contexto carcerário (alguns desses eventos contando com a presença de alguns desse profissionais). À título de esclarecimento, o processo de pesquisa ocorreu com menor intensidade no que tange à observação participação em eventos sobre as PSR, dada que a bolsita que havia iniciado o projeto se afastou da pesquisa, tendo sido substituída. Os eventos citados foram os seguintes:

a) Fórum de Debates em Setembro de 2017 com a presença da psicóloga Rosana ${ }^{4}$. Fórum de Debates é uma disciplina do curso de Psicologia do UniCEUB na qual promove eventos, palestras e debates sobre temas escolhidos pelos próprios estudantes. Nessa palestra que Rosana pode comparecer, ela discorreu sobre sua atuação, dificuldades e avanços realizados pela equipe de saúde na PFDF.

b) Palestra na semana da psicologia do UniCEUB em Agosto de 2017, na qual a psicóloga Camila, profissional do Complexo Penitenciário da Papuda, compartilhou dados e experiências com os presos que foram cruciais para as reflexões desse campo de pesquisa.

c) Palestra "Meninas fora da lei" com egressas do sistema socioeducativo e a Dra Débora Diniz, autora do livro "Cadeia: Relatos sobre Mulheres", sobre etnografia realizada no Presídio Feminino do Distrito Federal.

d) Participação da 1a Jornada Internacional de Pesquisadores e Profissionais do Cárcere, dezembro de 2017, na Universidade Católica de Brasília. O Evento contou com Drạ Deuselita Martins, diretora da PFDF e demais pesquisadores de outras regiões e presídios. Informações compartilhadas por ela nesse evento foram de grande contribuição para o conhecimento da estrutura física e atribuições dos espaços, por meio de imagens expostas em sua apresentação sobre a PFDF.

Tanto as entrevistas semiestruturadas como a observação participantes foram aplicadas e analisadas a partir da inspiração teórica da cartografia de Guattari e Rolnik

\footnotetext{
${ }^{4}$ Os nomes das entrevistadas aqui mencionadas são fictícios de modo a preservação de sua identidade.
} 
(2000). Tal inspiração advoga no sentido de mapear territórios e modos de subjetivação que envolvem os profissionais da psicologia no que tange as suas práticas em relação a grupos vulneráveis. Dessa forma, na análise das entrevistas, foram elencadas quatro categorias analíticas, levando-se em consideração os sistemas de símbolos mobilizados pelas entrevistadas "em seus próprios termos" (Geertz, 1989), bem como os processos de subjetivação das psicólogas enquanto profissionais atuando na PFDF e no Consultório de Rua numa sociedade marcada por desigualdades (Guatarri e Rolnik, 2000).

As quatro categorias analíticas retiradas nas falas das entrevistadas são: 1 . as escolhas e oportunidades na formação com vistas a realização de uma psicologia com compromisso social; 2. os dilemas da atuação profissional cotidiana; 3 . as estratégias práticas de atuação envolvendo enfrentamento à violações de direitos humanos, e, por fim, 4. as conexões presentes entre a rua e o presídio, tema sobre o qual discorremos somente a partir das Considerações finais deste artigo.

Por fim, o projeto da pesquisa foi aprovado pelo Comitê de Ética do Centro Universitário de Brasília (UniCEUB) por envolver pesquisa com seres humanos.

\section{Resultados}

Como resultado da pesquisa, definimos quatro tópicos analisadores baseados nas falas das entrevistadas: 1. as escolhas e oportunidades na formação com vistas a realização de uma psicologia com compromisso social; 2. os dilemas da atuação profissional cotidiana; 3. as estratégias práticas de atuação envolvendo enfrentamento à violações de direitos humanos, e, por fim, 4 . as conexões presentes entre a rua e o presídio, tema sobre o qual discorremos a partir das Considerações finais deste artigo. Em cada um dos tópicos apresentados a seguir apresentaremos, primeiramente, os "achados" e interpretações acerca das psicólogas da PFDF e, posteriormente, a respeito das falas das psicólogas do Consultório de Rua, buscando, em momentos oportunos, realizar ligações e divergências entre os dois casos. 


\subsection{As escolhas e oportunidades na formação com vistas a realização de uma} psicologia com compromisso social

Em geral, a formação do profissional da psicologia é orientada sob uma visão de atendimento a um público elitizado, tornando o olhar para o usuário parcial, pois não leva em consideração as dinâmicas, contextos sociais e individuais de grupos vulneráveis, tal como as PSR. Segundo Bicalho (2009: 21) "a psicologia, hegemonicamente, tem se constituído como ferramenta de adequação e ajustamento "intimizado", universal e ahistórico;" o que vem contribuindo para uma Psicologia que pensa o ser humano descolado de seu contexto social e cultural, se tornando uma ferramenta médica, higienista e elitista. No entanto, alguns autores, tais como Bock (1999), apontam a necessidade de que o trabalho do profissional da psicologia não somente deva contribuir, mas também deve estar constantemente presente e auxiliando a transformação social, não somente para as populações vulneráveis, mas também da população brasileira. Essa atuação de uma Psicologia implicada com as questões sociais, deve, segundo Bock (1999, p. 328), identificarse com "as necessidades de nosso povo e acompanhar o movimento destas necessidades, sendo capazes de construirmos, sempre e permanentemente, respostas técnicas e científicas".

$\mathrm{Na}$ análise sobre as escolhas e oportunidades na formação das psicólogas entrevistadas, vemos como relevante apontar o papel das escolhas teóricas e práticas das profissionais ao longo desse processo. Suas escolhas ocorreram por influência de atuação em estágios, leituras de inclinação política-epistemológica crítica, ou por uma inclinação pessoal explícita mediada por valores como a cooperação, mas essa lógica não se aplica a todas, como veremos. No caso das psicólogas da PFDF, a aproximação de temáticas interdisciplinares, discussões feministas pensadas nas mulheres em situação de vulnerabilidade e o pensar teórico acerca do humano para além de perspectivas individualizadas, mas inseridas em compreensão estruturais, compõem o corpo teórico que atravessa o processo de formação profissional dessas psicólogas. Nesse sentido, compreender e aprofundar-se em reflexões referentes aos meios em que as subjetividades se emancipam em uma lógica capitalística (ROLNIK E GUATTARI, 2000), produz a possibilidade destas profissionais ocuparem um espaço de sujeito-psicólogas, saindo de um 
estado de alienação de sua própria identidade enquanto atuantes em uma "instituição total" (GOFFMAN, 1999) e pensando em garantia de direitos e cuidado.

Percebemos, nesse sentido, que para a ocorrência de uma perspectiva crítica diante de um ambiente marcado pelo endurecimento é de fundamental relevância um autoquestionamento diário frente a sua atuação, o que demanda o contato com o outro mediado por uma sensibilidade ética (RESENDE \& COSTA, 2017). É interessante perceber que a revolução molecular ${ }^{5}$, que chamamos aqui de ação emancipatória das profissionais da PFDF, se dá em um nível subjetivo devido a sua escolha de trabalhar com o quê e quem está à margem. Portanto, compreender e fazer uma leitura de teorias feministas, por exemplo, em seu contexto relacional pode ser um primeiro passo na composição da atuação profissionais em assistência a grupos vulneráveis.

Vimos até aqui que praticar direitos humanos em uma instituição total se relaciona com uma escolha reflexiva que a profissional coloca em prática. A atuação pautada em direitos humanos não parte de uma visão utilitária, mas reflexiva sobre como se instrumentalizar frente às violações de direitos enfrentadas pelas internas. Tal ideia se evidencia na fala de Eva sobre os instrumentos de direitos humanos aprendidos em sua formação:

“[...] Foi um caminho que eu trilhei sozinha. Não foi nada que eu fiz durante a graduação. Foi mais durante o mestrado. Na minha pesquisa de mestrado eu trabalhei muito essa questão da falta de política pública mesmo, do tanto que isso acaba gerando um momento de dissidência mesmo com violência contra a criança, né, principalmente com as mulheres agressoras". (Eva, Abril de 2018)

Eva optou por ter contato mais próximo com pessoas em situação vulnerável antes de ingressar enquanto psicóloga na PFDF. Anteriormente, ela trabalhou por 3 anos no Centro de Referência Especializada de Assistência Social (CREAS), com crianças que sofriam abuso. Estuda desde a sua graduação população que sofre violência. Teve experiência com creche e abrigo antes de assumir o cargo na Secretaria de Saúde como psicóloga da PFDF. Suas áreas de interesse no mestrado se relacionavam às mulheres agressoras de crianças.

\footnotetext{
${ }^{5}$ Compreendemos revolução molecular de acordo com a mesma perspectiva de Rolnik e Guattari (2000: 127): uma revolução que se dá em sincronicidade com os níveis infrapessoais, pessoais e interpessoais. pp.46 "O molecular, como processo, pode nascer no macro. O molar pode se instaurar no micro"
} 
Por outro ângulo, Rosana ao longo de sua carreira prévia ao presídio, nos relatou que suas escolhas profissionais eram orientadas por uma perspectiva clínica e hospitalar. Durante a graduação, ela era concursada da Secretaria de Educação, e tinha um desejo muito grande para atuar na clínica tradicional com o setting terapêutico individual. Rosana relata que teve como meta profissional participar do concurso para a Secretaria da Saúde do DF com a expectativa de atuar em hospitais. No entanto, foi designada para atuação na Penitenciária contra sua própria vontade; o que tende a surtir efeitos na sua motivação prática. Portanto, o caso de Rosana nos faz deduzir que nem toda atuação do profissional da psicologia na assistência a grupos vulneráveis se faz de modo engajado e por escolha própria. No entanto, Rosana atualmente sente-se como uma profissional que aprendeu a estar na instituição.

Outro eixo de análise que cabe elucidarmos neste tópico se refere à visão construída pelas psicólogas acerca da população assistida por elas. Ao perguntar para Eva se a sua visão sobre as mulheres encarceradas sofreu mudanças entre o período em que estava em formação universitária e depois que ela passou a atuar no presídio, ela nos contestou:

“A minha visão não mudou muito não, pra te falar a verdade, sabe? Eu digo que o trabalho do CREAS, ele me preparou muito pra trabalhar no presídio. Porque no CREAS eu só atendia pessoas em situação de vulnerabilidade social, né? E lá, como eu era referência da violência contra a criança, apesar do CREAS não trabalhar, pela política, tá escrito que a gente não trabalha com agressor, como eu trabalhava com a criança, os principais agressores eram os pais, né? E dependendo do tipo de violência, a principalmente a mãe, acabava que eu trabalhava muito com as ofensoras já, mas era outro tipo de crime. Então a minha visão não mudou muito. Já era muito mais social,entendeu, do que, é... Enfim, eu tenho uma visão muito mais social da coisa mesmo, sabe? O problema é muito maior e do jeito que está, e que as coisas estão caminhando, só vai piorar, só vai inchar mais o presídio". (Eva, Abril de 2018)

A fala de Eva nos faz refletir sobre a vinculação que ela encontra entre suas reflexões sociais e estruturais sobre grupos vulneráveis e a sua atuação como profissional da Psicologia. Percebemos que as escolhas, sejam teóricas ou práticas, que mobilizam profissionais, com Eva, a atuarem no ambivalente carcerário ou em outros espaços de diálogos com o enfrentamento às violações de direitos são orientadas por uma visão que não reduz os problemas dos sujeitos a seus aspectos individuais, mas busca uma interconexão complexa entre o individual e o social. Esse ponto nos abre também uma outra 
via de análise, agora sobre a atuação dessas profissionais, no que tange a interdisciplinaridade como possibilidade de atuação "rizomática".

Na pesquisa realizada com psicólogas que assistem PSR, no que tange a sua formação prévia temos que ambas as psicólogas nos colocaram a importância de suas decisões pessoais que foram independentes do contexto de formação para que se direcionassem a atuar junto com as PSR. Marta, por exemplo, nos disse que não teve em nenhum momento da sua formação universitária como psicóloga contato com temáticas ou matérias sobre direitos humanos das populações vulneráveis de nossa sociedade. Quando perguntada sobre disciplinas ou atividades de pesquisa ou extensão durante sua formação universitária acerca do tema, Marta nos respondeu o seguinte: “Nada, gente, na minha época de graduação nada, não tive contato com nada disso. Nada mesmo." (Marta, Abril de 2018).

Marta nos relatou que assim que se formou em Psicologia no final dos anos 1990 foi atuar no campo clínico psicanalítico com crianças, atuação que durou, aproximadamente, vinte anos. Portanto, em sua trajetória profissional, a psicóloga relata que a aproximação com as PSR é recente e fruto, segundo ela, de um desejo e anseio pessoal de oferecer mais de seu trabalho à sociedade; o que vem lhe causando uma sensação individual de encaixe com a profissão

\footnotetext{
"Mais recente esse meu desejo veio de uma maneira muito pessoal, assim de tentar levar o que eu tenho hoje de bagagem e do que eu tenho meu pra oferecer, eu percebi que aqui eu teria muito mais oportunidade de contribuir nessa população, nesse serviço itinerante, sabe, na rua. Eu me encaixo mais com o que eu tenho para oferecer como psicóloga e como pessoa, nesse trabalho hoje, me vejo muito mais encaixada." (Marta, Abril 2018)
}

Liliam, por sua vez, aponta a importância de uma decisão e motivação individual do estudante universitário de estudar e direcionar sua profissão para práticas que considera significativa; o que, para ela, indicava uma significação em relação a compromissos sociais. Ela aponta a importância de um alinhamento da profissão com seus valores ético-morais e políticos.

“Parte do aluno tentar construir uma trajetória significativa pra você porque a aula é padronizada e é igual pra todo mundo, mas o que que você vai fazer que tem haver com você, como é que você vai tornar sua prática significativa, como é que você vai tomar algo que te diz respeito que te traga, pelo menos pra mim é importante uma sensação de que eu estou fazendo algo que eu acredito..." (Liliam, Abril de 2018) 
No caso de Liliam a aproximação com o contexto da rua e das PSR dialoga muito com as suas afinidades com o estudo do social, próprio das Ciências Sociais, em interface com o estudo do individual, próprio da Psicologia. Além disso, a psicóloga nos disse que se preocupava com os processos de marginalização e exclusão sociais das PSR. Para ela a vida desses sujeitos é uma constante violação de direitos, por isso a psicóloga direcionou seus estudos para se aproximar deste público.

Liliam nos contou que cursou apenas uma matéria obrigatória no período da graduação e outra optativa que se dedicaram a abordar as temáticas relacionadas a Psicologia Social crítica, e que tinha um olhar para grupos vulneráveis, entre eles, PSR. Após essa disciplina, ela, por vontade própria, optou por fazer estágio no Consultório de Rua, estágio que, segundo ela, mudou sua percepção de mundo, e consequentemente o seu rumo acadêmico. O relato de Liliam nos faz refletir que cursos de graduação com abertura para temáticas sociais e críticas no seu "programa acadêmico" podem contribuir para a construção de trajetórias profissionais como a dela, ou seja, compromissadas com a melhoria da qualidade de vida e enfrentamento de violações de direitos humanos de grupos vulneráveis.

Por fim, vimos que em relação às escolhas e oportunidades na formação com vistas a realização de uma psicologia com compromisso social, as quatro psicólogas entrevistadas indicaram que o trabalho do profissional da psicologia nos contextos do cárcere e da rua se deram por escolhas engajadas socialmente, mais individuais do que motivadas pelo incentivo externo de uma formação universitária. Suas escolhas ocorreram por influência de atuação em estágios, leituras de inclinação política-epistemológica crítica, ou por uma inclinação pessoal explícita mediada por valores como a cooperação. No entanto, nem todas as entrevistadas se engajaram por escolha própria, já que uma delas, tendo sido aprovada em concurso público, foi designada para atuação na Penitenciária contra sua própria vontade; o que tende a surtir efeitos na sua motivação prática.

\subsection{Os dilemas da atuação profissional cotidiana}

A respeito dos dilemas de atuação profissional cotidiana das psicólogas que atuam atendendo a população carcerária da PFDF, temos que atualmente, oscila em média de 700 a 800 mulheres. O Presídio Feminino do Distrito Federal é o único presídio que acolhe 
exclusivamente mulheres no DF, portanto, esse número diz respeito a população carcerária do DF. No ano de 2003, através da Portaria Interministerial n¹.777 ocorreu a aprovação da "Saúde Prisional", no entanto, apenas em 2014 tal medida passou a ser uma política Nacional de Atenção Integral à Saúde das Pessoas Privadas de Liberdade no Sistema Prisional (PNAISP) no âmbito do SUS (SECRETARIA DE SAÚDE DO DISTRITO FEDERAL, 2018). Médicos, enfermeiros, técnicos de enfermagem, cirurgião dentista, técnico de saúde bucal, psicólogo, assistente social, farmacêutico, psiquiatra, terapeuta ocupacional e fisioterapeuta compõe a equipe multiprofissional de saúde nas penitenciárias do DF e os atendimentos são realizados semanalmente de segunda a sexta-feira nos períodos matutinos e vespertinos. No que tange ao atendimento psicológico, atualmente temos duas psicólogas atuantes na Penitenciária.

Em relação atuação das psicólogas PFDF, segundo Diniz (2015) e as entrevistadas, temos que a penitenciária não tem galpão para saída externa e todas as mulheres estão alocadas no mesmo ambiente, tanto as que estão em prisão preventiva ou provisória, quanto as que já receberam sua pena. Segundo a psicóloga Rosana, que atua na Penitenciária, na estrutura arquitetônica do presídio, o núcleo de atendimento psicológico é o espaço com a estrutura mais precária. A sala de atendimento das internas é descrita como um "puxadinho", um "cafofo", espaço improvisado para dar conta do atendimento. Portanto, a clínica psicológica no presídio ocorre em um contexto limitado. Nestas salas de atendimento não há isolamento acústico, por serem essas separadas por divisórias de plástico ${ }^{6}$, logo, o som é audível entre as salas, o que, imagina-se, afeta os diálogos. Além disso, o espaço de sigilo e intimidade entre as profissionais e as internas é ainda mais limitado pela presença de uma terceira pessoa, um profissional da escolta em frente à porta.

De acordo com as interlocutoras da PFDF, também, a forma de atendimento psicológico se dá por meio de atendimento individual no qual as internas solicitam o atendimento e então ele é agendado pelas psicólogas, sendo que em casos de emergência a solicitação é advinda da equipe de segurança. Outro tipo de atendimento ocorre com os programas de acompanhamento realizados em grupos: de gestantes, das puérperas, o que são qualificados por alguma demanda judicial das internas, de fortalecimento das mulheres prestes a começar a trabalhar e das que saem para trabalhar. Pretende-se implementar

\footnotetext{
${ }^{6}$ O material da divisória é de PVC.
} 
ainda o que elas chamaram de "roda de terapia comunitária" com as internas, os visitantes, agentes sociais e penitenciários; essas rodas almejam discutir e propor as soluções para os problemas levantados por essa comunidade de pessoas. Até o momento das entrevistas, essa estratégia começou a ser implementada apenas com o grupo das internas. $O$ grupo que envolve as gestantes trabalha com os profissionais da enfermagem em decorrência de dúvidas físicas e clínicas por parte das internas. Ainda acerca do cotidiano de trabalho relatado pelas entrevistadas, ressaltamos que elas relataram realizar um trabalho em conjunto constante com o assistente social da equipe de profissionais atuante no presídio.

Rosana e Eva nos indicaram que trabalhar com o público vulnerável que são as mulheres encarceradas é algo que demanda uma atenção diferenciada. Primeiramente, pelo fato de ser uma atuação imersa em uma instituição fechada, bem como pelas vicissitudes da população assistida. Segundo o instituto ANIS - Bioética realizou no ano de 2012 um censo no PFDF de modo a identificar muitas características de mulheres encarceradas no Presídio, uma das vicissitudes das internas são as marcas de violência sexual, urbana e pobreza sofridas por essas mulheres ao longo de suas respectivas trajetórias de vida. Ademais, muitas delas em suas biografias, já passaram por centros socioeducativos antes dos 18 anos de idade e seu ingresso no mundo do crime se trata de uma experiência próxima aos familiares de modo a sustentar a casa (DINIZ, 2015).

Além do que foi dito, é importante nos atentarmos às complicações estruturais e burocráticas citadas pelas psicólogas como exemplo de dificuldade de sua atuação no contexto carcerário. No que concerne a estrutura da PFDF, como já foi relatado, não é possível haver sigilo na clínica, além de muitos dos atendimentos serem cancelados de última hora, o que impossibilita o processo terapêutico das usuárias ser contínuo. No que tange às demandas burocráticas, a própria Secretaria de Saúde do DF ao dispor e alocar seus recursos a diversos ambientes nos quais ela atua, não prioriza o presídio, segunda Rosana e Eva. Em vista disto, Eva nos relatou que, no seu caso, há o desejo de um aumento de carga horária de trabalho para que seja feito um trabalho mais consistente no Presídio, entretanto, seu pedido de aumento de horas não foi liberado pela Secretaria até o momento da entrevista. Este problema é ainda mais complexo pelo fato de que a população medida da PFDF hoje é de 700 mulheres, no entanto, o número de psicólogas disponíveis para atendêlas é de apenas duas. 
Um outro eixo de análise para refletirmos os desafios de atuação das psicólogas na PFDF, trata-se de sua vulnerabilidade enquanto mulheres em um ambiente marcado pela violência e dominação masculina. Acerca disso, Eva nos relatou que, certa vez, em um contexto de terapia de grupo umas das internas teria levantado sua voz a ela, que esperava poder ter construído algum nível de reflexão sobre a emoção expressa por essa interna. No entanto, no mesmo momento um escoltante adentrou o espaço do grupo e retirou a interna, cortando o processo terapêutico, que dificilmente seria restabelecido.

O trecho a seguir expressa uma fala de Eva bastante significativa sobre os temas até aqui discutidos.

\begin{abstract}
“Grupos a gente faz dentro das salas com as internas, mas aí a gente adapta né, aí a gente faz grupos menores. Não tem como fazer grupo muito grande lá. A gente pergunta geralmente se são internas que oferecem algum tipo de perigo né. Porque tem umas que são mais perigosas e acaba que quem tá... Existe um código de ética deles também né, é... e quem geralmente dança nisso é o pessoal da saúde. Então, eles não compram, as internas, né, os internos também, porque no masculino acaba que é muito assim. Se fizer alguma coisa com um agente, a retaliação vai ser muito maior do que com alguém do núcleo de saúde, então acaba que a gente tá numa situação vulnerável lá também, né.

É.. a gente só atende com escoltante né, que nem eu te falei. Tem a dificuldade do sigilo, que não tem como garantir sigilo. Não tem como fazer terapia, né, a gente faz assim, aconselhamento terapêutico nos atendimentos individuais. Até pq somos 2 psicólogas pra 700 internas, então eu não consigo acompanhar essas mulheres com muita frequência" (Eva, Abril de 2018).
\end{abstract}

Um outro obstáculo para a atuação na PFDF concerne à interpretação errônea acerca do trabalho realizado pelas psicólogas. Segundo o Código de Ética profissional é vedado ao psicólogo realizar avaliação e laudos criminológicos. Podemos considerar, de acordo com as interlocutoras desta pesquisa, que estar em uma situação de subalternidade à uma autoridade que demanda esse tipo de atuação configura-se enquanto um espaço desfavorável a práticas que visam a emancipação das internas. O trecho a seguir da fala de Eva aponta essa dificuldade com relação aos documentos:

"Muita demanda do juiz pedindo avaliação psicológica. A gente responde que 'aqui a gente não faz esse tipo de trabalho mas aqui ela está em acompanhamento pra diminuir os agravos do aprisionamento'. Já aconteceu de vir reclamação do juíz, ou então de juíz tirar pedaço de relatório e colocar na sentença dele com CRP, com nome da pessoa. Dependendo do que a pessoa fez, é colocar o psicólogo em risco, se a pessoa sair. Então tem muito essa cobrança assim do judiciário meio que pra 'deixa eu ver se consigo tirar essa pessoa e consigo colocar 
isso nas costas do psicólogo', entendeu? E o psicólogo falar que a pessoa tá apta ou não. Não é meu trabalho." (Eva, Abril de 2018)

Não obstante, tivemos o relato de uma complicação que ocorreu após a emissão de um parecer acerca da situação de uma interna no qual constava o CRP de uma das psicólogas. Conforme relatos, tal situação gerou sensação de insegurança para a psicóloga e os sentidos atribuídos a essa experiência acabaram por ser de desamparo frente às instituições responsáveis pelo processo. Este fato nos traz à tona uma reflexão a ser feita sobre a complexidade dos contextos, muitas vezes marcado pelo medo, em que os profissionais da psicologia se inserem e a necessidade de mecanismos de proteção desses profissionais.

Ainda, um fenômeno que nos afetou durante o processo de pesquisa, a partir das leituras, entrevistas e olhar cartográfico produzido, foi o fato relatado pelas psicólogas e percebido pelas pesquisadoras de que muitos profissionais que atuam no ambiente prisional tendem a se ver limitados em suas possibilidades de produção criativa de novas práticas, novos devires, bem como se veem sujeitos a mecanismos de ajustamento em relação às regras rígidas de relacionamento neste contexto. Além disso, esses profissionais têm que lidar com possibilidades de serem usados pelas internas como meios de que esses obtenham algum benefício extra, o que foi relatado pelas psicólogas como causando um mal estar e um olhar desconfiado em relação ao público que assistem. Esse processo se soma a uma percepção de ausência de investimentos e valorização do sistema prisional por parte do Estado. A partir de uma leitura Rolnik e Guattari (2000), que abordam o tema das subjetividades moleculares, potencialmente emancipatórias, identificamos no processo descrito uma tendência não emancipatória, ou seja, sujeições que produzem subjetividades que tendem a limitar o espaço de ação desses profissionais, o que estamos chamando aqui de "relações endurecidas" traçadas na instituição carcerária da PFDF. Como desenvolvemos nas seções adiante, estes profissionais se veem diante de paradoxos em sua ação, pois, por um lado, há possibilidades emancipatórias de se ter uma atuação crítica, reflexiva e que dialogue com o enfrentamento às violações de direitos humanos; por outro lado, esses profissionais se veem assujeitados a subjetividades endurecidas. O fenômeno que estamos tentando mapear que parece ser comum no contexto prisional brasileiro, em geral, fato que só poderemos constatar em futuras pesquisas. No caso de nossa pesquisa nos chamou a atenção os vários relatos sobre os profissionais em geral que atuam na Penitenciária sendo 
muitas vezes inflexíveis frente às relações com as mulheres assistidas, bem como o endurecimento dos diálogos. Timerman (2017), em outro contexto, relata em seu livro "Desterros" a própria experiência na psiquiatria de um sistema penitenciário em São Paulo, no qual em seus primeiros meses de atuação, sentia-se acuada e se encolhia quando um agente penitenciário chamava atenção de algum preso. No entanto, a autora abre mão de uma auto observação na qual se questiona se a segurança deixou de tão rígida ou se "os quatro anos endureceram a mim. Deixei de escutar as repreensões como absurdas. Torneime, também, parte do absurdo" (Ibid: 30-31). Nesse sentido a autora aponta a reflexão sobre os limites de já não ouvir mais esse tipo de atitude ou ter se acostumado com os gritos abusivos. Vimos no caso relatado pela autora um devir de endurecer-se como uma possibilidade de um não ouvir mais o outro. Endurecer-se, portanto, pode significar não ouvir, desconfiar, desanimar-se com os limites a sua ação criativa, diminuir sua relacionalidade empática com o público assistido, entre outras ações.

A partir das informações descritas e discutidas sobre o caso da PFDF, temos que é muito importante elucidar que as consequências das limitações da dinâmica do espaço, dos recursos escassos e pouca valorização estatal, do excesso de burocracias, regras a serem seguidas e das dinâmicas relacionais tensas entre profissionais e internas, fenômenos próprios da "instituição total" que é a PFDF, geram afetações nos modos de agir por parte das psicólogas. Esse tema nos faz refletir sobre a condição mais geral das pessoas em conflito com a lei, pois se os profissionais que, em tese, poderiam contribuir com sua melhoria de qualidade de vida ou redução dos agravos do aprisionamento se vêm compelidos a "endurecer-se", esse público de pessoas em conflito com a lei continua com os seus processos de emancipação limitada; expressão de uma condição estrutural de um sistema que enxerga as pessoas em conflito com a lei como descartáveis ou até mesmo como importantes apenas para a legitimação de uma ordem social (COIMBRA, 2001).

No que compete a atuação das psicólogas dentro do Consultório na Rua, bem como, segundo as entrevistas, em outras instituições de auxílio a PSR, o "fazer" da clínica psicológica tradicional é confrontado, sendo necessária a configuração de uma nova forma de interação com os sujeitos assistidos, novas formas de um atuar psicológico são criadas a cada momento, dentro de uma perspectiva de experimentação que busca atender as especificidades das PSR e suas condições complexas, tal como a psicóloga Marta narra no trecho a seguir. 


\begin{abstract}
"Eu percebo que a minha atuação ela é muito mais no sentido de uma escuta, e muitas vezes de uma intervenção breve mesmo, então eu pontuo coisas, trabalho questões, às vezes em uma sessão que talvez num protocolo mais da psicoterapia a gente demoraria mais tempo pra estar trabalhando, sabe? Mas aqui é 'levantou, cortou', falou 'opa, é agora!', então você já manda algumas pontuações realmente mais diretas, entendeu?. E muitas vezes sem esperar aquele insight que vai vir, entendeu? Então muitas vezes o paciente deu alguma brecha que ele está entendendo o que você tá falando, eu já 'pá, então é isso, Fulano, é isso mesmo, eu acho que você deve pensar por aí, refletir um pouco em relação a isso', e com isso eu consigo vincular com eles" (Marta, Abril de 2018)
\end{abstract}

Marta aponta que as vezes o usuário aparece apenas uma vez para atendimento pontual e tendem a retornar muito raramente. Ela diz que muitas vezes aquele momento terapêutico único pode ser suficiente para produzir intervenções significativas, pois, segunda ela, este momento pode representar um resgate da PSR no sentido de um autocuidado e da ressignificação de suas experiências cotidianas, e até mesmo de um acesso a outros direitos.

Acerca do resgate do sentido do autocuidado, Marta nos relatou um caso de um senhor que possuía um quadro de Sífilis, mas ao invés de querer trata-la ele priorizou "tratar" da sua tristeza. Ela indica que sua reação inicial seria leva-lo para algum atendimento de saúde, mas o senhor pede para ela que queria apenas conversar. Ela então se propõe a conversar com o Senhor, mas sem negligenciar o fato de que ele também deve cuidar da saúde.

"O sujeito chega aqui com tantas questões que ele precisa resolver, então desde a ferida, da micose, do pé rachado, da tuberculose, da sífilis, e da tristeza, ele prefere conversar sobre a tristeza do que tratar a sífilis dele e eu acolho isso e eu converso. Então: 'outro dia você para a gente começar seu tratamento da sífilis?' 'Venho'. Então é isso, é o nosso tratamento. 'E hoje então nós vamos só conversar'. E aí eu atendo uma hora e tal às vezes, e é isso que o sujeito precisa, vai embora feliz, agradecido, sorrindo, então pronto, era isso." (Marta, Abril de 2018)

Acerca do tema dos direitos, Marta diz que seu papel enquanto psicóloga, muitas vezes, é de auxiliar a terem seus direitos atendidos, tais como atendimento à saúde, já que ela acompanha pessoas a irem a hospitais ou outros serviços de saúde, até de cuidado higiênico no próprio Consultório de Rua; ou mesmo de um atendimento que oriente as PSR relacionada a questões civis e legais, tais como a solicitação de documentos (identidade, passe livre, etc). 
Um fator complexo acerca desse tipo de atendimento civil e legal, citado por Marta, é que muitos a procuram solicitando ajuda para conseguir laudos médicos para que possam ter acesso a algum benefício. $\mathrm{O}$ caso mais corriqueiro é o laudo de HIV.

\footnotetext{
“O HIV hoje, não basta ter o diagnóstico, o sujeito tem que estar adoecido para ter direito, né, e isso aí é uma questão super complicada pra gente isso, porque a grande maioria escuta falar que tem... 'ai, quem tem AIDS, quem tem HIV tem direito' e até a gente explicar isso é difícil, porque eles ficam muito bravos aqui, agridem, alguns ficam muito mesmo indignados e não entendem direito essa lógica do INSS." (Marta, Abril de 2018).
}

Um outro eixo de discussão que as psicólogas nos provocam a refletir acerca do seu papel em relação a PSR no DF é sobre a relação com o tempo e do espaço das PSR, bem como de suas prioridades quando solicitam atendimento no Consultório de Rua. Marta narra que a marcação de horários com os usuários do Consultório de Rua não é nada convencional relacionado a um atendimento psicoterápico particular. Por exemplo, ela cita que não adianta indicar um horário (15h) para o usuário, pois as dinâmicas relacionadas a seu cotidiano o colocam diante de uma relação com os horários que não convergem com a dinâmica metrificada do tempo, que orienta as relações de trabalho clássicas. Muitas vezes o paciente pode nem aparecer ou chegar, inusitadamente, em outros horários no Consultório de Rua. Liliam, por sua vez, aponta que a hora de comer de várias PSR, por exemplo, é a hora que a pessoa tem fome e não é determinada necessariamente por uma convenção social de seguir um horário de almoço para honrar um horário de trabalho.

Liliam, ainda, nos coloca que a relação de tempo e espacialidade de muitas PSR que ou vivem há muito nessa situação ou nasceram em situação de rua é marcada por uma lógica da vida cotidiana que não permeia a ideia de casa como espaço fixo, de trabalho formal estável, de posses patrimoniais e econômicas. Essas ideias-força de nossa sociedade hegemônica podem gerar a sensação de aprisionamento para muitos, segundo Liliam. Esse tema nos coloca diante do que Rolnik e Guatarri (2000) nos apontam sobre as subjetividades capitalísticas que permeiam as relações sociais hegemônicas no nosso meio social. Acerca do conceito apresentado, Rolnik e Guatarri (2000, p. 22) definem subjetividades capitalísticas como "indivíduos normalizados, articulado uns aos outros segundo sistemas hierárquicos, sistemas de valores, sistemas de submissão." A reflexão de Liliam também nos lembra da afirmação de Bauman (2005, p. 42) “onde há projetos há refugo." Onde necessariamente 
reside projetos, existe refugo, pessoas na quais iram ficar a margem e não conseguiram realizar esse "projeto". Dentro da realidade da rua as PSR sempre vão estar a margem, sempre serão refugadas, pois não seguem e se enquadram nessa lógica social de fazer e ter projetos de vida, como hegemonicamente a sociedade exige um projeto de vida, essa pessoas são excluídas.

\footnotetext{
"Tem pessoas que nasceram na rua. Elas nunca fizeram parte dessa lógica. Você coloca ela dentro de uma casa, ela se sente presa, ela se sente restringida, ela sente que... Nossa, ela não aumentou, restringiu a liberdade dela, agora ela tem que trabalhar para pagar essa casa, para pagar a conta de luz, para pagar IPTU e não sei o quê, e não é isso que ela quer. Ela quer viver de outro modo. E assim, é um outro modo, é uma temporalidade diferente, é uma organização psíquica diferente, mas a gente tem que aprender a lidar com isso, né? $\mathrm{E}$ a gente tem que tentar compreender."(Entrevista Liliam, 2018).
}

Por fim, a respeito aos dilemas da atuação profissional cotidiana em ambos os casos aqui analisados encontramos limitações de espaço de atuação que impossibilitam um setting de atendimento terapêutico tradicional, limites burocráticos que demandam relatórios, documentações e produtividade da atuação profissional que restringe a prática da psicologia nos contextos da rua e do presídio, bem como a dinamicidade dos tempos e condições dos próprios grupos vulneráveis em atendimento, tal como a lógica não convencional do "tempo da rua" ou da totalidade da privação, própria da "instituição total" carcerária.

\subsection{As estratégias práticas de atuação envolvendo enfrentamento à violações de} direitos humanos

Levantamos nesta sessão algumas das estratégias que nossas interlocutoras nos apontaram sobre suas práticas cotidianas instrumentalizadas num olhar crítico sobre os contextos em que atuam, bem como recursos oriundos da formação em Psicologia para tal.

Para discutir as estratégias práticas de atuação envolvendo enfrentamento à violações de direitos humanos das mulheres em situação de cárcere, utilizamos o conceito de rizoma. Para Deleuze e Guattari (1996) o termo foi importado da biologia para apontar o que se difere, aquilo que pode ter origens diversas e difusas. Nesse sentido, entendemos que a atuação das psicólogas no sistema carcerário envolve criar capilaridade ou rede com a atuação de outros profissionais da Psicologia e profissionais de outras áreas. Identificamos que o trabalho na penitenciária, feito por equipes interdisciplinares de saúde, cria relações 
rizomáticas, ou seja, a atuação das psicólogas da PFDF encontra formas diferenciadas de atuação mesclando práticas de profissionais de outras áreas. Por exemplo, Eva diz que é seu papel informar as internas sobre seus direitos, incorporando uma linguagem jurídica para sua atuação, apontando para as mulheres "você tem direitos, você não está desassistida".

Outro caso citado por Eva e Rosana é o fato de que, eventualmente, ocupam tarefas organizacionais do presídio, tal como organizar filas em dias de vacinação, uma tarefa própria da gestão da instituição. Ainda no que tange as atuações as psicólogas apontam que produzem diálogos esporádicos, informais ou formais, com as psicólogas do Complexo Penitenciário da Papuda, outra penitenciária do DF. Por fim, criaram uma rede de diálogos via whatsapp com profissionais da assistência social e psicologia do DF, externa a PFDF, para garantir meios de acompanhamento em relação a saúde mental das egressas da PFDF. Tal medida aponta novas formas de cuidado e preocupação com a saúde mental dessas pessoas bem como um compromisso com a dignidade delas. Essa medida é apresentada por Eva a seguir:

\footnotetext{
“Muitas vezes a gente entra em contato já com o lugar se ela precisa, sei lá, de um caps. A gente já entra em contato com um CAPS, já tenta conversar e falar das necessidades. Mas com as que a gente consegue fazer a gente já entrega um encaminhamento pra elas" (Eva, Abril de 2018).
}

Complementar ao que foi exposto anteriormente, podemos também nos aproximar de uma visão de "rede rizomática" (CARVALHO \& FRANCO, 2015), devido às conexões que se articulam no meio com a própria comunidade composta por agente penitenciários, psicólogas, assistente social, médicas, internas e também os familiares. Ainda neste ponto, podemos fazer um paralelo com as participações de movimentos sociais no Sistema Único de Saúde (SUS), Quintanilha, Sodré e Dobello-Araújo (2013) mostram que essas podem ser caracterizadas como rizomáticas por não serem preestabelecidas, mas sim emergentes das relações entre os trabalhadores que as compõem. O mesmo processo, portanto, foi visto no contexto penitenciário, já que a equipe de saúde atuante na PFDF é interdisciplinar.

Um outro eixo a ser analisado são as formas de tratamento das profissionais com as internas, como por exemplo Rosana relata não gostar de usar o termo interna com elas pois elas têm nome e não devem ser tratadas de forma massificada, ignorando as singularidades de cada mulher. Nesse sentido, desvela-se uma dimensão do cuidado e do próprio uso dos direitos humanos enquanto emancipador dentro da lógica da instituição total, que de 
acordo com Goffman (1999), tende mortificar o eu, ou seja, a ação de Rosana rompe com essa lógica institucional da prisão.

Uma outra estratégia de atuação que Rosana e Eva buscam é de implementar os grupos comunitários nos quais a própria comunidade apresenta resoluções para seus problemas. A estratégia de uma terapia comunitária tem potencial de criar uma forma de reconhecimento de processos em comum e incentivar um ambiente mais cooperativo.

Por outro lado, uma perspectiva feminista aparece de forma expressiva no que tange ao uso de recursos e instrumentos utilizados pelas psicólogas para uma atuação reflexiva frente aos direitos humanos: a visão de que é possível empoderar uma mulher que em outros espaços não têm acesso aos serviços de saúde e à assessoria jurídica. Esse empoderamento facilita as mulheres garantirem seus direitos fundamentais. Segundo Eva, nas estratégias de trabalhos em grupos, citados anteriormente, discutir questões amorosas é necessário, em decorrência de boa parte das mulheres encarceradas já terem sofrido abusos, violências sexuais e físicas de parceiros. No trecho a seguir, Eva discorreu um pouco sobre a sua forma de atuar com as mulheres encarceradas. Ela aponta o uso de uma abordagem feminista que visa um empoderamento e emancipação, especialmente de mulheres com histórico de violência:

\footnotetext{
"Eu trabalho lá com processo de subjetivação em gênero. Eu uso terapia de abordagem feminista também lá dentro né, e é uma das coisas que mais uso lá dentro mesmo. Pra trabalhar a questão de empoderamento, pra trabalhar, é.. situações que às vezes elas viveram e que elas nem percebem como violência. Você pega mais de $90 \%$ das mulheres no presídio, sofreram violência, entendeu? E muitas não conseguem perceber. Às vezes elas tão lá porque sofreram violência e aí aconteceu uma coisa: ou retaliou ou, enfim, deu algum problema lá que ela acabou sendo presa. Então um dos trabalhos, é, uma das coisas que quero fazer ainda é: eu quero fazer um grupo pra discutir questões amorosas porque muitas vão parar lá por causa de 'ah matei meu namorado', 'meu namorado me batia'. Isso uma interna me contou um tempo atrás. Eu uso muito esse trabalho lá com gênero desconstruindo muitas questões e outras também pra isso, tanto pra empoderar quanto pra elas terem uma outra percepção de si." (Eva, Abril de 2018)
}

No escopo de atuação das profissionais há também o acompanhamento com as gestantes e as puérperas. A maternidade é vista enquanto uma forma de identidade para muitas dessas mulheres. No entanto, ao serem separadas de suas crianças ocorre uma quebra identitária dentro de uma instituição total que já a destituiu de boa parte do que as definiam enquanto mulher e pessoa. A estratégia das psicólogas é realizar uma transição de cuidado com as mãe que concebem seus filhos no cárcere, de modo que quando a criança 
for retirada da mãe, ela possa ter uma das psicólogas ou a assistente social acompanhando na entrega para outra pessoa. No trecho a seguir, Eva aborda a complexidade dessa questão em suas várias nuances:

\begin{abstract}
“Uma das coisas que a gente faz lá é que, o momento da retirada da criança é muito difícil, muito difícil pra elas né. É uma quebra identitária pra elas ali dentro. Muitas desorganizam. começas a ter, se tinha já algum tipo de sintoma, o sintoma aparece mais forte, começa a ter ideação suicida. Aí esse programa de acompanhamento q a gente faz com as gestantes e as puérperas é que a ideia é que elas possam fazer uma transição de cuidado, então quando a criança vai ser retirada dela, pela polícia, a ideia é que ela possa entregar aí assim ou eu, ou a Rosana ou a assistente social acompanha a entrega da criança." (Eva, Abril de 2018)
\end{abstract}

No caso das mulheres que não sabem o destino dos filhos que estão fora desse contexto, Eva coloca que um dos papéis relevantes para sua atuação e de Rosana frente ao enfrentamento das violações aos direitos humanos, vincula-se a um caráter informativo. Ela nos relatou que muitas das mulheres que estão encarceradas não sabem o que é um psicólogo e nesse sentido, o atendimento muitas vezes é de uma orientação de como a interna pode buscar assessoria jurídica, visto que em muitos casos elas desconhecem seus próprios direitos. Com relação às mães que não sabem onde estão seus filhos, Eva, no trecho a seguir, nos elucida essa situação:

“Eu acho que lá a gente é, tanto eu quanto a Rosana, a gente é atuante sim nessa questão dos direitos humanos, seja no mínimo assim, no empoderamento dessa mulher de falar, olha 'você tem direito, você não tá desassistida, eu to aqui como, é meu trabalho, minha obrigação te informar' e muitas vem com o discurso 'ai brigada, doutora' que é muito comum esse discurso com a população vulnerável, né, de não perceber aquilo como um direito, mas perceber aquilo como uma favor. $\mathrm{E}$ a gente sempre bate nessa tecla, de não, a gente tá aqui também pra falar disso, pra acionar 'ah cê não sabe onde tá seu filho, então vamos acionar os órgãos competentes lá fora pra saber'. Isso também é uma forma de atuação. E eu acho que essa coisa de conseguir, de tentar, eu ainda quero fazer, se rolar de dobrar minha carga horária e tal, quero fazer vários outros grupos assim. Tenho muita vontade de fazer grupo pra desconstruir a questão amorosa com elas, pra falar dessa questão da maternidade, do cuidado com a criança que na nossa sociedade é todo concentrado na mulher e, enfim, a sociedade toda tem que contribuir com isso, no apoio da formação da criança. Eu trabalho com a crença de que isso é uma forma de empoderar essas mulheres nisso também assim 'você tem direito' assim 'você nunca teve acesso a nada, mas você tem direito a isso, isso e a isso' entendeu? Assim, um trabalho informativo também que muitas não sabem nem ao que elas tem direito, né, onde pode procurar, o que que pode procurar." (Eva, Abril de 2018)

Após desenvolvido as especificidades da atuação das psicólogas nesse contexto, é relevante apresentar um outro aspecto que se refere à medicamentalização das mulheres encarceradas. Rosana desde o início de sua atuação vem desenvolvendo uma política de 
redução do uso de medicamentos psicotrópicos, que segundo ela, é uma estratégia de cuidado fundamental para a produção de bem estar das internas. Nos foi relatado que há 4 anos atrás, por volta de 400 internas faziam uso de medicação, mas, após a implantação da equipe de saúde e atualmente apenas 32 dessas mulheres são medicadas (até o momento das entrevistas). Outro cuidado relatado pelas interlocutoras concerne à redução de automutilação por parte das internas. Rosana nos disse que em muitos casos, ao invés de fazer um requerimento de atendimento com as psicólogas, ocorria a automutilação como uma forma de chamar atenção dos profissionais para que elas pudessem "conversar" com alguém da equipe de saúde. Eva pontua em sua fala a seguir, alguns dos frutos dessas práticas emancipatórias de minimização de danos frente à diminuição do uso de medicamentos, bem como da automutilação:

\footnotetext{
"Tem muito transtorno de adaptação também que elas chegam lá é muito difícil, é outro convívio, assim, é outra realidade, é outro mundo o presídio. Com outras regras, com outro funcionamento. E aí elas tem que se adaptar àquilo, então muitas têm o transtorno de adaptação também. Apresentam muito problema com ansiedade, é.. automutilação tem demais, mas a gente conseguiu fazer, principalmente a Rosana que esse foi um trabalho que começou a ser feito há alguns anos, assim, há uns 4 anos. Antes, há uns 4 ou 5 anos atrás, a metade da cadeia tomava medicação psicotrópica. Assim, exorbitante o número, e aí com o fortalecimento do trabalho tanto do psiquiatra quanto da psicologia, a gente conseguiu reduzir esse número. Hoje são 32 que tomam. É só quem realmente precisa. Aí hoje elas passam, quando precisa de uma medicação psicotrópica, passa primeiro por uma avaliação psicológica, a gente conversa com o psiquiatra, e aí passa pro psiquiatra. Mas só depois dessa avaliação. Lá tem muito pedido de, elas pedem remédio pra traficar. Porque muitas estão abandonadas, não tem dinheiro, precisam de dinheiro lá dentro e remédio lá dentro é dinheiro, então é isso. E elas já sabem certinho assim. Lá todo mundo é "doutô" né, então "doutora me dá um amytril, me dá levozine" já sabe certinho qual que é a medicação." (Eva, Abril de 2018)
}

Por fim, partindo das reflexões acerca da redução do uso de medicamentos psicotrópicos ser um resultado de uma escuta maior das demandas das internas, destaca-se a relevância do papel primordial de um psicólogo em qualquer contexto de atuação: a escuta. No caso da penitenciária, a escuta atenta e empática desenvolvida na relação entre psicólogas e internas, indica um meio transformador da experiência no cárcere, especialmente para as mulheres que cotidianamente tem seus direitos violados nessa instituição.

No que compete a atuação das psicólogas dentro do Consultório na Rua, bem como, segundo as entrevistas, em outras instituições de auxílio a PSR, o "fazer" da clínica 
psicológica tradicional é confrontado, sendo necessária a configuração de uma nova forma de interação com os sujeitos assistidos, novas formas de um atuar psicológico são criadas a cada momento, dentro de uma perspectiva de experimentação que busca atender as especificidades das PSR e suas condições complexas, tal como a psicóloga Marta narra no trecho a seguir.

\begin{abstract}
"Eu percebo que a minha atuação ela é muito mais no sentido de uma escuta, e muitas vezes de uma intervenção breve mesmo, então eu pontuo coisas, trabalho questões, às vezes em uma sessão que talvez num protocolo mais da psicoterapia a gente demoraria mais tempo pra estar trabalhando, sabe? Mas aqui é 'levantou, cortou', falou 'opa, é agora!', então você já manda algumas pontuações realmente mais diretas, entendeu?. E muitas vezes sem esperar aquele insight que vai vir, entendeu? Então muitas vezes o paciente deu alguma brecha que ele está entendendo o que você tá falando, eu já 'pá, então é isso, Fulano, é isso mesmo, eu acho que você deve pensar por aí, refletir um pouco em relação a isso', e com isso eu consigo vincular com eles" (Marta, Abril de 2018)
\end{abstract}

Marta aponta que as vezes o usuário aparece apenas uma vez para atendimento pontual e tendem a retornar muito raramente. Ela diz que muitas vezes aquele momento terapêutico único pode ser suficiente para produzir intervenções significativas, pois, segunda ela, este momento pode representar um resgate da PSR no sentido de um autocuidado e da ressignificação de suas experiências cotidianas, e até mesmo de um acesso a outros direitos.

Acerca do resgate do sentido do autocuidado, Marta nos relatou um caso de um senhor que possuía um quadro de Sífilis, mas ao invés de querer trata-la ele priorizou "tratar" da sua tristeza. Ela indica que sua reação inicial seria leva-lo para algum atendimento de saúde, mas o senhor pede para ela que queria apenas conversar. Ela então se propõe a conversar com o Senhor, mas sem negligenciar o fato de que ele também deve cuidar da saúde.

"O sujeito chega aqui com tantas questões que ele precisa resolver, então desde a ferida, da micose, do pé rachado, da tuberculose, da sífilis, e da tristeza, ele prefere conversar sobre a tristeza do que tratar a sífilis dele e eu acolho isso e eu converso. Então: 'outro dia você para a gente começar seu tratamento da sífilis?' 'Venho'. Então é isso, é o nosso tratamento. 'E hoje então nós vamos só conversar'. E aí eu atendo uma hora e tal às vezes, e é isso que o sujeito precisa, vai embora feliz, agradecido, sorrindo, então pronto, era isso." (Marta, Abril de 2018)

Acerca do tema dos direitos, Marta diz que seu papel enquanto psicóloga, muitas vezes, é de auxiliar a terem seus direitos atendidos, tais como atendimento à saúde, já que 
ela acompanha pessoas a irem a hospitais ou outros serviços de saúde, até de cuidado higiênico no próprio Consultório de Rua; ou mesmo de um atendimento que oriente as PSR relacionada a questões civis e legais, tais como a solicitação de documentos (identidade, passe livre, etc).

Um fator complexo acerca desse tipo de atendimento civil e legal, citado por Marta, é que muitos a procuram solicitando ajuda para conseguir laudos médicos para que possam ter acesso a algum benefício. O caso mais corriqueiro é o laudo de HIV.

“O HIV hoje, não basta ter o diagnóstico, o sujeito tem que estar adoecido para ter direito, né, e isso aí é uma questão super complicada pra gente isso, porque a grande maioria escuta falar que tem... 'ai, quem tem AIDS, quem tem HIV tem direito' e até a gente explicar isso é difícil, porque eles ficam muito bravos aqui, agridem, alguns ficam muito mesmo indignados e não entendem direito essa lógica do INSS." (Entrevista Marta, 2018).

Um outro eixo de discussão que as psicólogas nos provocam a refletir acerca do seu papel em relação a PSR no DF é sobre a relação com o tempo e do espaço das PSR, bem como de suas prioridades quando solicitam atendimento no Consultório de Rua. Marta narra que a marcação de horários com os usuários do Consultório de Rua não é nada convencional relacionado a um atendimento psicoterápico particular. Por exemplo, ela cita que não adianta indicar um horário (15h) para o usuário, pois as dinâmicas relacionadas a seu cotidiano o colocam diante de uma relação com os horários que não convergem com a dinâmica metrificada do tempo, que orienta as relações de trabalho clássicas. Muitas vezes o paciente pode nem aparecer ou chegar, inusitadamente, em outros horários no Consultório de Rua. Liliam, por sua vez, aponta que a hora de comer de várias PSR, por exemplo, é a hora que a pessoa tem fome e não é determinada necessariamente por uma convenção social de seguir um horário de almoço para honrar um horário de trabalho.

Liliam, ainda, nos coloca que a relação de tempo e espacialidade de muitas PSR que ou vivem há muito nessa situação ou nasceram em situação de rua é marcada por uma lógica da vida cotidiana que não permeia a ideia de casa como espaço fixo, de trabalho formal estável, de posses patrimoniais e econômicas. Essas ideias-força de nossa sociedade hegemônica podem gerar a sensação de aprisionamento para muitos, segundo Liliam. Esse tema nos coloca diante do que Rolnik e Guatarri (2000) nos apontam sobre as subjetividades capitalísticas que permeiam as relações sociais hegemônicas no nosso meio social. Acerca do 
conceito apresentado, Rolnik e Guatarri (2000, p. 22) definem subjetividades capitalísticas como "indivíduos normalizados, articulado uns aos outros segundo sistemas hierárquicos, sistemas de valores, sistemas de submissão." A reflexão de Liliam também nos lembra da afirmação de Bauman (2005, p. 42) “onde há projetos há refugo." Onde necessariamente reside projetos, existe refugo, pessoas na quais iram ficar a margem e não conseguiram realizar esse "projeto". Dentro da realidade da rua as PSR sempre vão estar a margem, sempre serão refugadas, pois não seguem e se enquadram nessa lógica social de fazer e ter projetos de vida, como hegemonicamente a sociedade exige um projeto de vida, essa pessoas são excluídas.

"Tem pessoas que nasceram na rua. Elas nunca fizeram parte dessa lógica. Você coloca ela dentro de uma casa, ela se sente presa, ela se sente restringida, ela sente que... Nossa, ela não aumentou, restringiu a liberdade dela, agora ela tem que trabalhar para pagar essa casa, para pagar a conta de luz, para pagar IPTU e não sei o quê, e não é isso que ela quer. Ela quer viver de outro modo. E assim, é um outro modo, é uma temporalidade diferente, é uma organização psíquica diferente, mas a gente tem que aprender a lidar com isso, né? E a gente tem que tentar compreender."(Entrevista Liliam, 2018).

Por fim, em geral, no que tange às estratégias práticas de atuação envolvendo enfrentamento à violações de direitos humanos, temos que, durante a atuação, todas as profissionais entrevistas se veem diante de possibilidades de intervirem de modo inovador visando a emancipação dos públicos assistidos, através da criação de redes informais de diálogo, no caso da penitenciária, entre egressas e redes de atendimento psicossocial; e através da orientação, tanto das mulheres encarceradas quanto das pessoas em situação de rua, no sentido de recorrer aos seus direitos fundamentais, bem como de entender que têm recursos para isso.

\section{Considerações Finais}

À título de finalização deste projeto de pesquisa, consideramos importante dizer que nossa pesquisa encontrou algumas conexões importantes entre a rua e o presídio nas falas das entrevistadas, tema que nos aponta caminhos para futuras pesquisas. Segundas todas as entrevistadas, muitas pessoas em situação de rua já passaram pelo sistema prisional, bem como muitos dos egressos, ou pessoas em liberdade condicional, acabam por retornar ao sistema carcerário devido as suas "redes da rua", marcadas por "richas", "acertos de contas" 
ou esvaziamento de laços que levam egressos do cárcere a viverem na rua. Além disso, muitas mulheres, tanto encarceradas quanto em situação de rua, têm seus filhos realocados em abrigos, o que ocasiona uma fragilidade de seus vínculos afetivos e uma quebra identitária em relação à sua maternidade. Percebe-se, também, uma exclusão estrutural sistemática de pessoas negras e pobres, bem como de mulheres e crianças, percorrendo estes dois contextos sociais continuamente de modo interconectado. Por fim, entre a rua e o presídio se vê uma submissão feminina expressa em sua vulnerabilidade na rua, que coloca as mulheres em situação de rua muitas vezes sob a tutela de algum homem "protetor", processo que, muitas vezes, as insere no mercado ilegal do tráfico de drogas e, consequentemente, no sistema prisional. As conexões entre a rua e presídio é um tema cheio de lacunas que nos foi apontado nas falas das entrevistadas, portanto, consideramos tais conexões uma importante temática a ser melhor investigadas pela ótica da atuação do profissional da Psicologia nas interfaces com os direitos humanos. Futuras pesquisas poderão buscar mapear e cartografar as práticas "psi" que visam produzir atenção e cuidado na rua e no presídio e entre a rua e o presídio, entendendo que os dois "espaços" dialogam profundamente em termos sociais e culturais, não apenas pela sua marginalização social, mas por suas dinâmicas, linguagens, dramas e, como definimos, conexões comuns, demandando, por isso mesmo, maior atenção psicossocial. Analisar o continuum rua e presídio por parte da garantia de direitos das instituições estatais e das práticas profissionais da Psicologia que atua pode vir a nos ajudar a contribuir com os direitos humanos das pessoas em conflito com a lei e das pessoas em situação de rua.

Por fim, as falas das entrevistas nos coloca a questão da formação da Psicologia como um espaço que pode ampliar mais as possibilidades de espaços que diferem de uma clínica tradicional, aonde o profissional possa empregar diversos recursos e técnicas, algumas alternativas, outras experimentais e muitas inovadoras para melhor compreender os sujeitos. Segundo as quatro entrevistadas da pesquisa, no entanto, por mais inovadoras que sejam suas práticas, a escuta deve ter sempre a peça fundamental nas suas respectivas atuações.

Além disso, acreditamos que o como maiores achados da pesquisa temos que a percepção de que no contexto de atuação da psicologia envolvendo a rua e o presídio a prática profissional é suscitada grandemente por escolhas individuais mediadas pela formação universitária ou por valores sociais. Dessa forma, sugerimos que algumas 
disciplinas críticas, a experiência do estágio clínico com grupos vulneráveis e o contato com perspectivas teóricas críticas façam mais diálogos entre Ciências sociais, Psicologia, e direitos humanos, provocando mais estudantes a tomarem a decisão de se tornar um profissional da psicologia visando um compromisso social com grupos vulneráveis.

Ainda, paradoxalmente, como "achado", temos que a prática profissional da Psicologia diante do enfrentamento de violações de direitos humanos perpassa lógicas limitantes do próprio contexto de trabalho. Embora sejam possíveis intervenções críticas e emancipatórias, tais profissionais se veem muitas vezes diante de limitações e desengajamento em suas práticas, o que enxergamos como um certo tipo de endurecimento das subjetividades desses profissionais como psicólogos atuando nas fronteiras das interfaces com os direitos humanos.

Por fim, concluímos que escutar e analisar as percepções e experiências dos profissionais da Psicologia que atuam nos contextos do presídio e da rua, tal como fizemos, abre espaço para futuras pesquisas sobre o mesmo tema em outras localidades e em relação aos mais variados casos em ressonância temática em termos de se pretender estudar a atuação do profissional da psicologia em relação a grupos vulneráveis no Brasil, tal como os contextos aqui estudados. Essa espécie de etnografia da psicologia das interfaces com o enfrentamento a violações de direitos pode ser de grande contribuição para o entendimento da relação entre Psicologia e direitos humanos, bem como colaborar com subsídios para a formação da psicóloga a partir dos relatos práticos e experiências vividas dos profissionais em atuação. Entende-se como tarefa da formação em Psicologia abordar e incentivar um pensamento crítico e sensibilidade sobre a realidade, por meio de debates direcionados para uma práxis emancipatória. 


\section{REFERÊNCIAS BIBLIOGRÁFICAS}

ALMEIDA, Roberto. Estudo de Caso: foco temático e diversidade metodológica. Pesquisador do Cebrap 2016 e Professor do Departamento de Antropologia do IFCH/UNICAMP

ARAÚJO, E. Dal P. Vitimização carcerária: uma visão sociológica. In: PIEDADE JUNIOR, Vitimologia em debate II. Rio de Janeiro: Lúmem Júris, 1997.

BARCINSKI, Mariana; CUNICO, Sabrina Daiana. The (un)visible effects of prison: the contradictions of the prison system. Psicologia, Lisboa, v. 28, n. 2, p. 63-70, dez. 2014.

BAUMAN, Zygmunt. No Começo era o projeto: ou o refugo da construção da ordem. Em: Vidas Desperdiçadas. Rio de Janeiro: Zahar, 2005, p. 17-45.

BICALHO et al. Formação em psicologia, direitos humanos e compromisso social: a produção micropolítica de novos sentidos. Boletim Interfaces da Psicologia da UFRRJ. Vol. 2, No. 2, Dezembro 2009.

BIROLI, Fávia; MIGUEL, Luis Felipe. Feminismo e política: uma introdução. São Paulo: Boitempo, 2014.

BOCK, Ana Mercês Bahia. A Psicologia a caminho do novo século: identidade profissional e compromisso social. Estud. psicol. (Natal)[online]. 1999, vol.4, n.2, pp.315-329.

BRASIL. DECRETO № 19.841, DE 22 DE OUTUBRO DE 1945. Disponível em: http://www.planalto.gov.br/ccivil 03/decreto/1930-1949/d19841.htm

BRASIL. Conselho Nacional do Ministério Público. Guia de Atuação Ministerial : defesa dos direitos das pessoas em situação de rua. Conselho Nacional do Ministério Público. - Brasília : CNMP, 2015.

BRASIL. Ministério do Desenvolvimento Social e Combate à Fome. Inclusão das Pessoas em Situação de Rua no Cadastro Único para Programas Sociais do Governo Federal. Volume 1. 2011.

BRASIL. Ministério da Saúde. O SUS de A a Z. 3ed. Brasília: Ministério da Saúde, 2009c. Disponível em: $<\mathrm{h} \$ \mathrm{p}: / /$ portal.saude.gov.br/portal/arquivos/pdf/sus_3edicao_completo.pdf $>$.

BRASIL. Ministério do Desenvolvimento Social e Combate. Política Nacional de Assistência Social - PNAS. Ministério do Desenvolvimento Social e Combate à Fome Secretaria Nacional de Assistência Social. Brasília, novembro de 2005

BRASIL. Ministério do Desenvolvimento Social e Combate à Fome. Rua: Aprendendo a contar. Pesquisa nacional sobre a população em situação de rua. Brasília, DF: MDS: Secretaria de Avaliação e Gestão da Informação. Secretaria Nacional de Assistência Social. 2009. 
BRASIL. Ministério da Saúde. Saúde da População em Situação de Rua: Um direito humano. Ministério da Saúde. Secretaria de Gestão Estratégica e Participativa. Coordenação Geral de Apoio à Gestão Participativa e ao Controle. Brasília, 2014.

BRASIL, Ministério da Justiça e Cidadania. Relatório INFOPEN Mulheres. 2015. Brasília. Disponível em: Disponível em: http://www.justica.gov.br/noticias/estudo-traca-perfil-dapopulacao-penitenciaria-feminina-no-brasil/relatorio-infopen-mulheres.pdf/view . Acesso em 14/01/2017.

CARDOSO, Lourenço. Branquitude acrítica e crítica: A supremacia racial e o branco antiracista. Rev. Latinoamericama de Ciências Sociais. 8 (1), 2010.

CARVALHO, ML, Valente JG, Assis SG, Vasconcelos AGG. Perfil dos internos no sistema prisional do Rio de Janeiro: especificidades de gênero no processo de exclusão social. Cien Saude Colet 2006; 11(2):461-471.

CARVALHO, Maria de Nasaré; FRANCO, Tulio Batista. Cartografia dos caminhos de um usuário de serviços de saúde mental: produção de si e da cidade para desinstitucionalizar. Physis: Revista de Saúde Coletiva, v. 25, p. 863-884, 2015.

CENTRO DE REFERÊNCIA TÉCNICA EM PSICOLOGIA E POLÍTICAS PÚBLICAS (CREPOP). Referência técnica para atuação do(a) psicólogo(a) no CRAS/SUAS. Conselho Federal de Psicologia (CFP). -- Brasília, CFP, 2007

CESARIO, R. P. Consultório na Rua: uma cartografia sobre as práticas profissionais. Brasília, UniCeub, 2017.

CESCR. CESCR General Comment 4: The Right to Adequate Housing, [7], UN Doc E/1992/23 (1992).

COIMBRA, C. M. B. Psicologia, Direitos Humanos e Neoliberalismo. In: Revista de Psicologia Política. São Paulo: Sociedade Brasileira de Psicologia Política. 2001.

Direitos humanos e a atuação na área jurídica. In Comissão Nacional de Direitos Humanos do Conselho Federal de Psicologia (Ed.), Os direitos humanos na prática profissional do psicólogo. Brasília, DF: Conselho Federal de Psicologia, 2003

COIMBRA, Cecília Maria Bouças; LOBO, Lilia Ferreira; NASCIMENTO, Maria Lívia do. Por uma invenção ética para os Direitos Humanos. Psicol. clin., Rio de Janeiro, v. 20, n., p. 89-102, 2008.

CONSElho federal De PSICOlOgIA. Código de Ética Profissional do Psicólogo, XIII Plenário. Brasília, DF: CFP. 2005

CONSELHO REGIONAL DE PSICOLOGIA MINAS GERAIS (CRP-MG). A Psicologia e a População em situação de rua: novas propostas, velhos desafios. Belo Horizonte: CRP 04, 2015 
DINIZ, Débora. Cadeia: relatos sobre mulheres. 1.ed. Rio de Janeiro: Civilização Brasileira, 2015.

Letras Livres. 2012

.Carta de uma orientadora: o primeiro projeto de pesquisa. Brasília. Ed.

.Pesquisas em cadeia. Rev. direito GV, São Paulo, v. 11, n. 2, p. 573-586, Dec.

2015.

DELEUZE, Guilles. Conversações. Rio de Janeiro: Editora 34. 1992

ESCOREL, S. Vidas ao léu: trajetórias de exclusão social. Rio de Janeiro: Fiocruz, 1999.

FANON, Frantz. Pele branca, máscaras negras. Trad. de Renato da Silveira. Salvador: Ed. UFBA, 2008.

FERRARI, Ilka Franco. Mulheres encarceradas: elas, seus filhos e nossas políticas. Rev. MalEstar Subj., Fortaleza, v. 10, n. 4, p. 1325-1354, dez. 2010.

FIGUEIRÓ, Martha Emanuela. Teatro-menor: cartografia em arte e experimentação de mulheres em situação de cárcere. Psicologia \& Sociedade, v. 26, 2014.

FIGUEIRÓ, Rafael de Albuquerque. Cartografia do trabalho de agentes penitenciários: reflexão sobre o "dispositivo prisão". 2015.

GIACOMELLO, C. Mujeres, delitos de drogas y sistemas penitenciarios en América Latina. International Drug Policy Consortium, 2013.

GUATTARI, F.; ROLNIK, S. Micropolítica. Cartografias do Desejo. Petrópolis: Vozes, 2000.

GUIMARÃES, Cristian Fabiano; MENEGHEL, Stela Nazareth; DE OLIVEIRA, Carmen Silveira. Subjetividade e estratégias de resistência na prisão. Psicologia: ciência e profissão, v. 26 , n. 4, p. 632-645, 2006.

LYNCH, Philip \& COLE, Jacqueline. Homelessness and Human Rights: Regarding and responding to homelessness as a human rights violation. Melbourne Journal of International Law. Volume 4. 2003.

MATTOS, Ricardo Mendes \& FERREIRA, Ricardo Franklin. Quem você pensa que (elas) são? Representações sobre as pessoas em situação de rua. Psicologia e Sociedade. 16 (2), 47-58, Ago/2004.

QUINTANILHA, B. C., Sodré, F., \& Dalbello-Araujo, M. Movimentos de resistência no Sistema Único de Saúde (SUS): a participação rizomática. Interface-Comunicação, Saúde, Educação, 17, 2013. 561-573. 
OLIVEIRA, Rayane Noronha. Mulheres, saúde reprodutiva e prisão: um estudo da maternidade em uma perspectiva feminista na Penitenciária Feminina do Distrito Federal. Monografia. Universidade de Brasília, Instituto de Ciências Humanas, Departamento de Serviço Social, 2014.

$\mathrm{s}$

OVINSKI DE CAMARGO CORTINA, Monica. Mulheres e tráfico de drogas: aprisionamento e criminologia feminista. Revista Estudos Feministas, Florianópolis, v. 23, n. 3, p. 761-778, nov, 2015.

PASSOS, Eduardo., KASTRUP, Virgínia, ESCÓSSIA, Liliana, Pistas do método da cartografia: Pesquisa-intervenção e produção de subjetividade. Porto Alegre: Sulina, 2009.

RAUTER, C. Clínica e estratégias de resistência: perspectivas para o trabalho do psicólogo em prisões. Psicologia e Sociedade, vol.19, n.2, 2007. pp. 42-47

RESENDE, Tania Inessa Martins; COSTA, lleno Izídio. Saúde mental: a convivência como estratégia de cuidado, dimensões ética, política e clínica. Curitiba: Juruá, 2017.

ROSATO, Cássia Maria. Psicologia e Direitos Humanos: cursos e percursos comuns. Psicologia Revista. Revista da Faculdade de Ciências Humanas e da Saúde. ISSN 1413-4063, [S.I.], v. 20, n. 1, p. 9-27, ago, 2011. ISSN 1413-4063.

SCHERER, Zeyne Alves Pires; SCHERER, Edson Arthur. Concepções e vivências de mulheres encarceradas sobre a violência. Cogitare Enfermagem, [S.I.], v. 14, n. 3, set. 2009.

SECRETARIA DE SAÚDE DO DISTRITO FEDERAL. Saúde prisional. Disponível em: <http://www.saude.df.gov.br/saude-prisional/>. Acesso em: 03 jul. 2018.

SOARES, Gabriela Pinheiro; FELIX-SILVA, Antônio Vladimir; FIGUEIRO, Martha Emanuela Soares da Silva. Teatro-menor: cartografia em arte e experimentação de mulheres em situação de cárcere. Psicol. Soc., Belo Horizonte , v. 26, n. spe, p. 89-99, 2014.

TÓTORA, Silvana. “Devires minoritários: um incômodo" in Verve. São Paulo, Nu-Sol, vol. 6, 2004. 